
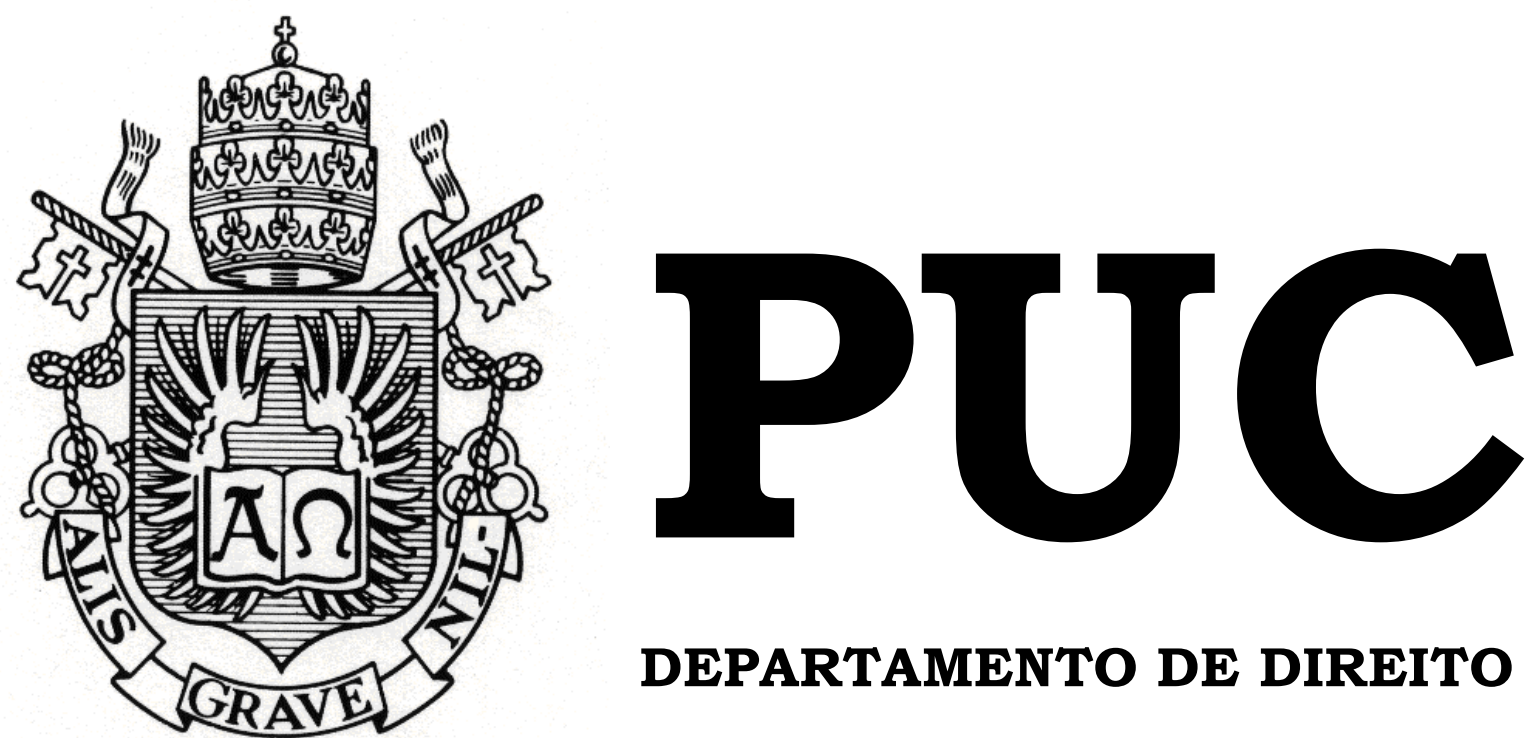

DEPARTAMENTO DE DIREITO

\title{
CONTRATOS DE EPC
}

por

AMANDA LEAL BRASIL

ORIENTADOR (A): GUILHERME BRECHBÜHLER CO ORIENTADOR (A): MARCELLO OLIVEIRA

$$
\text { 2011.1 }
$$

PONTIFÍCIA UNIVERSIDADE CATÓLICA DO RIO DE JANEIRO

RUA MARQUÊS DE SÃO VICENTE, 225 - CEP 22453-900

RIO DE JANEIRO - BRASIL 


\title{
CONTRATOS DE EPC
}

\author{
por
}

\section{AMANDA LEAL BRASIL}

Monografia apresentada ao Departamento de Direito da Pontificia Universidade Católica do Rio de Janeiro (PUC-Rio) como requisito parcial para a obtenção do Título de Bacharel em Direito.

Orientador(a):

Guilherme Brechbühler.

Co Orientador(a):

Marcello Oliveira.

2011.1 
À minha mãe e minha irmã, responsáveis pelo meu interesse pelo mundo jurídico. Sem a inspiração de vocês eu não teria chegado até aqui! 


\section{AGRADECIMENTOS}

Primeiramente, gostaria de agradecer ao meu co-orientador, Marcello Oliveira, que além de ter despertado meu interesse pelo tema desta monografia, me orientou de forma esclarecedora e instigante. Não tenho dúvidas de que aprendi muito nessas madrugadas de estudo, assim como também não tenho dúvidas de que o que aprendi será muito útil para minha carreira profissional.

Agradeço à minha mãe por me incentivar, acreditar em mim, no meu trabalho, no meu esforço e por vibrar comigo a cada vitória profissional. Agradeço também à pessoa mais inteligente e dedicada aos estudos jurídicos que eu conheço, minha irmã, que me inspirou a cada segundo nestes cinco anos de trajetória do curso de Direito da PUC. Dedico a vocês cada palavra deste trabalho.

Agradeço também às minhas queridas amigas que conquistei nesta faculdade e que com certeza levarei comigo para o resto da vida: Adriana Borges, Ana Luiza Valente Oazen e Paula Coutinho.

Finalmente, gostaria de agradecer à equipe do jurídico da OSX. Obrigada pela compreensão nestes agitados momentos de fim de curso e monografia e por todos os ensinamentos diários. É uma honra fazer parte dessa equipe, o que me faz, diariamente, perceber que o aprendizado em nossa carreira não tem limites. 


\section{RESUMO}

BRASIL, Amanda Leal. Contratos de EPC. Rio de Janeiro, 2011. 80p. Monografia de final de curso - Departamento de Direito. Pontifícia Universidade Católica do Rio de Janeiro.

O presente trabalho discorrerá sobre Contratos de EPC.

Iniciou-se o estudo com uma abordagem preliminar sobre os Contratos de EPC, seu contexto histórico e os motivos de sua introdução no Brasil. Falou-se da estrutura financeira do project finance e da importância dos Contratos de EPC para uma maior alocação dos riscos relacionados ao empreendimento. Foram analisadas também as principais características deste contrato, as partes envolvidas e suas modalidades.

No segundo capítulo foram estudados os princípios e classificações dos contratos em geral, bem como as características do contrato de empreitada, o qual mais se aproxima das características do Contrato de EPC.

Em seguida, nos subitens do Capítulo III, foram apontados os impactos mais relevantes que surgem quando da análise de um Contrato de EPC à luz da normatização aplicável ao contrato de empreitada. Constatou-se, no referente estudo, que quanto à natureza jurídica do Contrato de EPC, este pode ser entendido como um contrato atípico misto, dependente de uma detalhada regulação entre o contratante e Epecista, observando sempre as regras da empreitada.

Finalmente, o último capítulo foi dedicado à análise da padronização dos Contratos de EPC no mundo globalizado e das principais cláusulas que devem ser observadas para a boa negociação e redação de um Contrato de EPC.

Palavras-chave: Contratos de EPC, project finance, grandes obras de engenharia e empreitada. 


\section{SUMÁRIO}

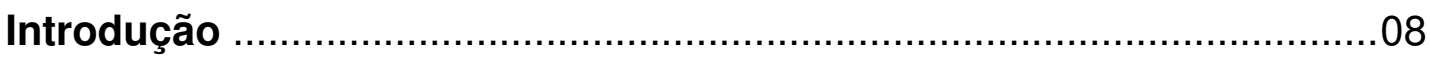

Capítulo I O Contrato de EPC: Uma abordagem preliminar ...................13

1.1. O contexto histórico e sua introdução no Brasil............................. 13

1.2. A importância do Contrato de EPC para o financiamento do projeto .........................................................................................17

1.3. Os elementos subjetivos do Contrato de EPC (o "Epecista" e o

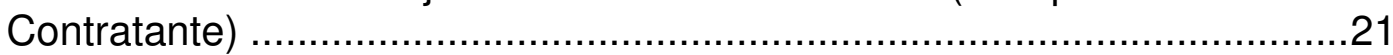

1.4. O Contrato de EPC Turnkey Lump Sum........................................ 24

Capítulo II Princípios e Classificações dos Contratos.............................28

2.1. Definição e Princípios fundamentais dos contratos.............................28

2.1.1. Princípio da autonomia da vontade das partes e o Princípio da função social do contrato ......................................................................29

2.1.2. Princípio da força obrigatória dos contratos e o Princípio da

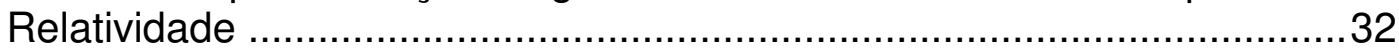

2.1.3. Princípio da boa-fé nos contratos ...............................................34

2.2. Classificação dos contratos (Típicos e Atípicos) ................................ 35

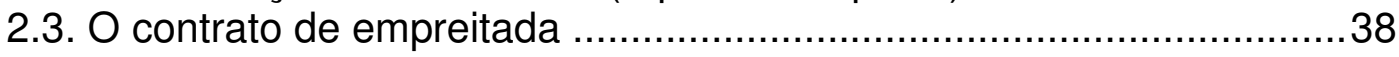

Capítulo III A Natureza Jurídica do Contrato de EPC …........................4 43

3.1. O Contrato de EPC à luz da normatização aplicável ao contrato

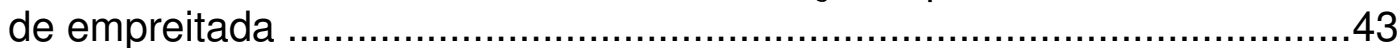

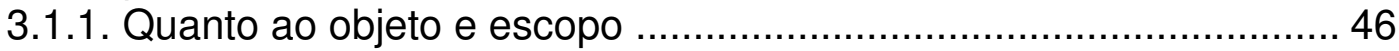

3.1.2. Caso Fortuito e Força Maior e os critérios objetivos de caracterização

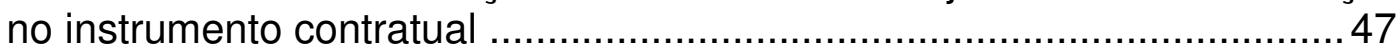

3.1.3. A garantia quinquenal e o repasse da garantia ............................50

3.1.4. A "hipossuficiência" do contratante e as ordens de mudança ........ 51

3.1.5. O pagamento e as medidas parciais do projeto (milestones) .......... 53

3.1.6. A aceitação dos trabalhos ........................................................ 54

3.2. A empreitada é a tipificação adequada ao Contrato de EPC?.............55

3.3. A não tipificação do Contrato de EPC no ordenamento jurídico

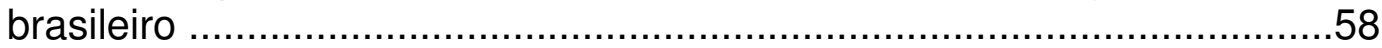

Capítulo IV O Contrato de EPC em outros países ................................6 60

4.1. A importância da padronização dos contratos ................................. 60

4.2. O Padrão da FIDIC para Contratos de EPC Turnkey Projects............ 62

4.3. Principais cláusulas que devem conter no Contrato de EPC .............66

4.3.1. Cláusula quanto ao prazo ..........................................................67

4.3.2. Cláusula quanto ao preço e forma de pagamento ........................... 68

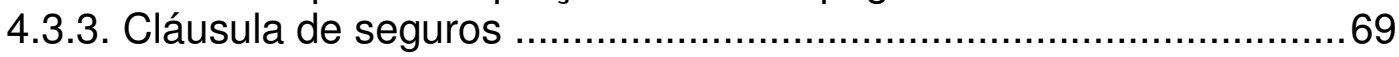

4.3.4. Cláusula de Caso Fortuito e Força Maior ………............................70

4.3.5. Cláusula de danos acordados.................................................... 71

4.3.6 Cláusula de bônus .................................................................. 
4.3.7 Cláusula de legislação aplicável, solução de controvérsias e foro... 73

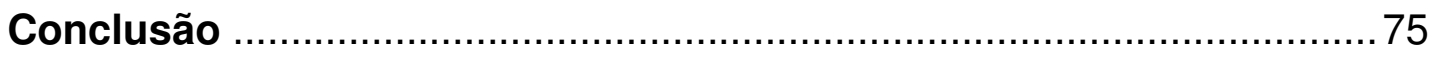

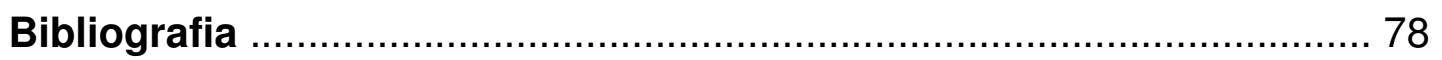




\section{ABREVIATURAS E SIGLAS UTILIZADAS}

EPC

BNDES

BID

IFC

$\mathrm{CCBC}$

DB

DBB

DBB-CM

SPE

JBIC

JCT

ICE

AIA

BKK

FIDIC

ICC

AAA

Lei de Licitações

Lei da Arbitragem

LCIA

LICC

Petrobras

Regime de Concessão de Serviços Públicos
Engineering, Procurement and Construction

Banco Nacional do Desenvolvimento

Banco Interamericano de Desenvolvimento

Internacional Finance Corporation

Câmara de Comércio Brasil Canadá

Design and Build

Design-Bid-Build

Design-Bid-Build-Construction, Management

Sociedade de Propósito Específico

Japan Bank for International Cooperation

Joint Contract Tribunal

Institute of Civil Engineers

American Institute of Arquitects

Byggandets Kontrackts Kommité

Federation Internacionale Des Ingenieurs-Conseils

International Chamber of Commerce

American Arbitration Association

Lei $\mathrm{n}^{\circ} 8.666$, de 21 de junho de 1993

Lei n. ${ }^{\circ}$ 9.307, de 23 de setembro de 1996

London Court of International Arbitration

Lei de Introdução ao Código Civil

Petróleo Brasileiro S.A. - PETROBRAS

Lei $\mathrm{n}^{\circ}$ 8.987, de 13 de fevereiro de 1995 


\section{INTRODUÇÃO}

O objeto do presente trabalho é a análise das principais características do Contrato de EPC diante da atual realidade da economia global e das práticas do mercado, que reforçam, no Brasil, a necessidade de planos governamentais e privados de investimentos em infraestrutura para dar sustentação ao desenvolvimento econômico e à capacidade de produção de riquezas.

Este estudo está dividido em quatro capítulos. No primeiro, foi tratada a contextualização do Contrato de EPC nos dias de hoje, a importância deste modelo de contrato para captar investimentos e as características peculiares deste tipo de contratação; no segundo capítulo, foram analisados os princípios gerais aplicáveis aos contratos, suas classificações e o contrato de empreitada; o terceiro capítulo tratou da natureza jurídica do Contrato de EPC; e finalmente, no quarto capítulo, discorreu-se sobre a importância da padronização do Contrato de EPC no mundo e suas principais cláusulas.

Julga-se interessante e conveniente dedicar o capítulo introdutório do presente trabalho à análise dos aspectos que levam à utilização do Contrato de EPC para a negociação de construções de grandes obras de engenharia.

A cada dia que passa as empresas patrocinadoras de grandes empreendimentos vêm utilizando estruturações cada vez mais sofisticadas para obter recursos financeiros necessários para sua implantação e operação. Esses empreendimentos, que demandam considerável quantia de capital, tem recorrido com frequência à estruturação financeira conhecida como project finance. Com isso, pretende-se alavancar ao máximo a capacidade de tomada do crédito do empreendedor, isolando-se as garantias do financiamento à empresa do projeto. 
Dentre eles, podem ser citados como exemplo a Ponte Rio-Niterói, que foi o primeiro trecho rodoviário privatizado no Brasil, a Usina Hidrelétrica de Itá, localizada no rio Uruguai, com capacidade para gerar $30 \%$ da demanda de energia do Estado do Rio Grande do Sul e o Campo Petrolífero de Marlim, o maior campo petrolífero em produção da Petrobras.

Apesar da explícita carência em sua área de infraestrutura, o Brasil apareceu na lista publicada em junho de 2010 pela KPMG, empresa de consultoria, que destacou mundo afora os cem melhores projetos em execução ou prontos para saírem do papel.

Segundo esse ranking, que levou em consideração aspectos como a complexidade de execução, a inovação empregada nas obras e o impacto sobre a sociedade, seis projetos brasileiros são apontados como exemplares: o Complexo Hidrelétrico do Rio Madeira (Jirau e Santo Antônio), o Centro Integrado de Ressocialização de Itaquitinga (PE), a Cidade Administrativa do estado de Minas Gerais, o Rodoanel Oeste de São Paulo, o Trem de Alta Velocidade, que ligará São Paulo ao Rio de Janeiro, e os terminais de regaseificação de gás natural construídos pela Petrobras que recebem o gás natural liquefeito para convertê-lo ao seu estado gasoso. ${ }^{1}$

Além destes, muitos empreendimentos de grande porte estão em andamento no Brasil. Exemplos não faltam, com a aproximação da Copa do Mundo, em 2014, e dos Jogos Olímpicos em 2016, que demandarão inúmeros equipamentos urbanos que interferem na mobilidade e qualidade de vida da população, tais como a construção e melhorias de aeroportos,

\footnotetext{
1 KPMG, Cutting Through Complexity. KPMG International and Infrastructure Journal Announce the Top 100 Infrastructure Projects. Disponível em: <http://www.kpmg.com/Ca/en/IssuesAndInsights/ArticlesPublications/Press-Releases/Pages/KPM GInternationalandInfrastructureJournalAnnouncetheTop100InfrastructureProjects.aspx $>$ Acesso em: 24 jun. 2010.
} 
teleféricos, estações de metrô e de trens, estações de saneamento, estádios, quadras poliesportivas, casas populares, entre outros.

Diante do aperfeiçoamento das demandas de infraestrutura no Brasil, e, consequentemente, do aumento do número de empresas solicitando financiamentos para viabilizarem os projetos, cria-se a necessidade de instrumentos econômicos, financeiros e jurídicos que facilitem o comprometimento e liberação desses valores ao empreendedor. Para que tal ocorra, faz-se necessário utilizar instrumentos jurídicos já conhecidos das instituições financeiras e bancos de desenvolvimento e fomento localizados no exterior.

Agentes financiadores como o BNDES, o Banco Interamericano de Desenvolvimento (BID), o Internacional Finance Corporation (IFC), o Japan Bank for International Cooperation (JBIC) e diversos bancos públicos e privados tendem a ser cada vez mais cautelosos quanto às suas aplicações, exigindo rigorosamente inúmeros estudos e pareceres de terceiros especializados quanto à viabilidade do projeto, bem como as regras que deverão estar refletidas nos instrumentos jurídicos, sob pena de não se realizar o financiamento.

Como exemplo, o BNDES, maior banco de fomento do país, impõe que na fase de implantação do projeto, a outorga de garantia fidejussória do beneficiário do investimento poderá ser dispensada, desde que haja celebração de contratos que obriguem os empreiteiros e/ou fornecedores de equipamentos a concluir o projeto dentro do orçamento predeterminado, em data previamente especificada e conforme as especificações técnicas destinadas a assegurar a operacionalização e o desempenho eficiente do projeto. $^{2}$

2 BNDES. O BANCO NACIONAL DO DESENVOLVIMENTO. BNDES Project Finance. Disponível em: < http://www.bndes.gov.br/SiteBNDES/bndes/bndes_pt/Institucional/Apoio_ Financeiro/Produtos/Project_Finance> Acesso em: 28 mai. 2011. 
Além disso, é essencial que os riscos do empreendimento sejam previamente identificados, para então, serem mitigados de várias formas, dependendo da sua natureza e impacto no empreendimento. Em outras palavras, os investidores exigem também que os riscos sejam alocados à parte que melhor possa gerenciá-los. Para isso, a alocação dos riscos terá como base os diversos instrumentos contratuais celebrados entre os participantes do empreendimento, que, em regra, são volumosos e bastante complexos.

Tendo em vista que a legislação brasileira não oferece, dentro dos contratos típicos previsto no Código Civil, um instrumento contratual adequado à estrutura financeira do project finance, o arranjo das cláusulas estipuladas no Contrato de EPC mostra-se como o modelo mais adequado, tanto para atender as exigências formuladas pelos agentes financiadores para a outorga do financiamento, quanto para estipular regras que definirão a postura a ser adotada pelo dono da obra e pela empresa contratada ao longo do projeto.

Os Contratos de EPC, de origem anglo-saxã, naturalmente possuem uma estrutura bastante complexa, pois obedecem aos cânones da common law, nem sempre auto-explicativos quanto ao regramento aplicável às partes em uma contratação de obra de engenharia . Por isso mesmo, trata-se de um contrato exaustivo, buscando esgotar as situações cotidianas mais problemáticas à convivência entre as partes. Um Contrato de EPC incompleto ou mal elaborado, que não prevê todas as situações que podem se concretizar, inevitavelmente aumentará a exposição do empreendedor ao risco de aumento dos custos do projeto e do prazo para sua finalização.

Isso porque, qualquer problema na fase de construção que não puder ser remediado de imediato, de acordo com o estipulado em suas cláusulas 
contratuais, sem dúvidas trará riscos à continuidade do projeto e às perspectivas de fluxo de caixa com a sua operação, criando, por via de consequência, problemas para o financiamento do projeto.

Assim, para que o Contrato de EPC possa ser utilizado com sucesso nas grandes obras de engenharia, é fundamental que haja uma extensa negociação da redação de suas cláusulas, envolvendo advogados e especialistas no assunto de modo a construir pontes entre os diversos interesses envolvidos, protegendo-os da melhor maneira possível, ou seja, alocando os riscos àquelas partes que têm melhores condições de suportálos.

Para isso, é essencial o conhecimento das características peculiares desta forma complexa de contratação que vem sendo cada vez mais adotada por proprietários de obras, construtores e operadores de grandes projetos de engenharia no mercado nacional e internacional, mas que ainda é muito pouco estudada em nosso país, carecendo de bibliografias sobre o assunto. 


\section{Capítulo I \\ O CONTRATO DE EPC: UMA ABORDAGEM PRELIMINAR}

Sumário: 1.1. O contexto histórico e sua introdução no Brasil; 1.2. A importância do Contrato de EPC para o financiamento do projeto; 1.3. Os elementos subjetivos do Contrato $(O$ "Epecista" e 0 Contratante); 1.4. O Contrato de EPC Turnkey Lump Sum.

\subsection{O contexto histórico e sua introdução no Brasil}

No Brasil, numa perspectiva desenvolvimentista, a partir da qual a industrialização seria o meio eficaz para vencer o subdesenvolvimento, o Estado atuou desde o final da década de 40 até o início dos anos 80, de maneira significativa nas áreas de planejamento, operação e financiamento dos setores de infraestrutura, particularmente nos de energia e transporte.

Nesta época, as grandes obras de engenharia eram realizadas pelo próprio governo ou por grandes empresas estatais que utilizavam da experiência de seus próprios quadros de empregados para elaborar os projetos de engenharia, os cronogramas e as especificações técnicas. Os construtores, por sua vez, eram contratados pelo menor preço, sendo certo que o escopo contratual era, em princípio, bastante limitado a etapas pontuais do projeto, sendo apenas estendido caso houvesse necessidade de subcontratação, aluguel de equipamentos e contratação de mão de obra adicional.

Praticava-se, então, o método de concepção de empreendimento hoje comumente designado como "DBB - Design-Bid-Build", ou "Projeto, Contratação e Construção", no qual o dono da obra assume o seu gerenciamento integral e contrata separadamente os serviços de engenharia (projeto), a aquisição de materiais e equipamentos, construção e montagem. 
Nesse formato, o construtor não atua de forma integrada com os demais fornecedores, responsabilizando-se o dono da obra pela integração dos diversos fornecedores de bens e serviços executados e pelos riscos inerentes a essa atividade.

Assim é que, nessa modalidade de execução, o dono da obra é responsável por avaliar a capacidade técnica, bem como os preços praticados pelos fornecedores de bens e serviços. A eventual inadequação ou insuficiência de tais bens ou serviços devem ser imputados e alocados ao dono da obra.

Atualmente, o método do DBB é mais adotado no Brasil na área pública. A Lei de Licitações, instituída pela Lei nº 8.666, de 21 de junho de 1993 permite a adoção desta modalidade objetivando, mediante a seleção entre vários fornecedores, a obtenção do menor preço. Contudo, um dos aspectos críticos relacionados a esse tipo de contratação é a qualidade do empreendimento que poderá ser comprometida, vez que será contratado aquele que oferecer o menor custo.

Ademais, outro aspecto crítico quanto ao DBB é que o prazo de finalização de todas as etapas do projeto acaba não sendo definido contratualmente e de forma integrada entre as diversas partes contratadas (projetistas, construtora civil e fornecedor de equipamentos), o que pode acarretar em obras inacabadas, desperdiçando milhões dos cofres públicos.

No entanto, a partir dos anos 80 o papel do Estado na economia começou a se modificar. A redução do ritmo de crescimento econômico mundial e o questionamento quanto à eficiência da atuação do Estado nos setores de infraestrutura reforçaram a necessidade dos governos federal e estaduais conceberem políticas sólidas de investimento nestes projetos, de 
modo a fomentar uma maior participação privada em setores essenciais da economia nacional.

Nesse contexto, começou a ser desenvolvido no Brasil um modelo de contratação visando um compartilhamento de riscos mais equilibrado, buscando-se empresa com experiência tanto na elaboração do projeto quanto na construção, de forma a gerenciar todo o empreendimento. Essa estrutura de contratação, na leitura atual, é chamada "DBB-CM - DesignBid-Build-Construction, Management" e é utilizada até hoje por algumas empresas estatais.

O modelo de contratação DBB-CM visava sanar a principal lacuna do modelo de contratação DBB, que era a falta de integração entre as partes relacionadas ao empreendimento. $\mathrm{Na}$ modalidade DBB-CM, a empresa construtora também é responsável, juntamente com o dono da obra e a empresa de engenharia, pelo gerenciamento da construção. Desta maneira, constituía-se uma responsabilidade compartilhada na medida em que o dono da obra contrata uma empresa de engenharia para trabalhar em parceria com a construtora.

Impulsionados pela aprovação do Regime de Concessão de Serviços Públicos, instituído através da Lei $\mathrm{n}^{\circ}$ 8.987, de 13 de fevereiro de 1995 e pela criação de regimes especiais de autorizações, incluindo para a exploração de geração de energia elétrica pelo setor privado, na modalidade "Produtor Independente de Energia" (Lei n 9.074/95), os investimentos de capital privado tornaram-se cada vez mais relevantes nos setores de energia elétrica, petróleo e gás, telecomunicações e transportes. ${ }^{3}$

\footnotetext{
${ }^{3}$ BONOMI, Cláudio A.; MALVESSI, Oscar. Project Finance no Brasil. São Paulo: Atlas, 2004. p. 67.
} 
Porém, para os investidores privados, que buscavam maior estabilidade e consistência quanto aos riscos do negócio, o DBB-CM não era suficiente. Isso porque, caso houvesse qualquer controvérsia entre as partes no âmbito da execução do contrato, tal metodologia não permitia que fosse delimitada a responsabilidade dos riscos do empreendimento a um único responsável, e isso resultava em atrasos nos prazos de entrega e aumentos dos custos de financiamento.

Tendo em vista que os projetos em tais setores se tornavam cada vez mais complexos no que se refere às disciplinas envolvidas, tornou-se imperiosa a contratação de empresas de engenharia que assumissem a realização de processos multidisciplinares, sem se limitar somente a determinadas etapas do empreendimento.

Ficou evidente que novas formas de gerenciamento eram necessárias para melhorar a eficiência e controle de evolução dos projetos. Além disso, era preciso estabelecer, em um único instrumento contratual, uma alocação de riscos que delimitasse a responsabilidade que cada parte assumia no contrato, preferencialmente desde a concepção do projeto básico até a entrega final da obra. Algumas vezes, até mesmo após a conclusão da obra, em que devem ser verificadas todas as condições técnicas necessárias ao correto desempenho das máquinas instaladas.

A fim de atender à nova realidade jurídica e econômica das contratações em andamento no país, o Contrato de EPC, cujas iniciais significam "Engineering, Procurement and Construction", já conhecido no mercado internacional, passou a ser largamente utilizado no Brasil. Assim, pretendeu-se sanar a carência de uma contratação única e integrada de todo o empreendimento, incluindo o projeto básico e detalhado de engenharia, construção civil, contratação de fornecedores, transporte, instalação, montagem de equipamentos e realização de comissionamento e testes. 
O Contrato de EPC passou, então, a ser o instrumento preferido pelos empreendedores para implantar grandes projetos, tais como construção de plataformas de petróleo, usinas térmicas, hidrelétricas e etc., nas quais revela-se fundamental: (i) a conclusão da obra dentro do cronograma estabelecido para que se evite perdas expressivas, eis que a produção desses empreendimentos deve ser, a priori, vendida para justificar o investimento na obra e (ii) o atingimento dos níveis de performance pré-estabelecidos, evitando-se frustrar a expectativa de fornecimento após o início da operação comercial.

Sobre as características próprias do Contrato de EPC, resumidamente explica JOSÉ VIRGÍLIO LOPES ENEI:

"O Contrato de EPC é o contrato pelo qual o contratado (epecista) assume a
responsabilidade integral pelo projeto (design), pelos serviços de engenharia e
administração (engeneering), pela construção civil (construct), pelo fornecimento
(suply) de materiais e equipamentos a partir de fontes próprias ou de terceiros
subcontratados (procurement), pela montagem e instalação dos equipamentos
(mounting, erection assembly), pelos testes e comissionamento dos equipamentos
(testing and comissioning), e por tudo mais que seja necessário à conclusão e
entrega da obra dentro das especificações e diretrizes definidas pelo contratante."

Pode-se concluir que o Contrato de EPC é, portanto, o instrumento jurídico através do qual o dono da obra (contratante) delega à contratada (chamada Epecista) os riscos e as responsabilidades de execução de um empreendimento em sua integralidade, compreendendo, entre estes, a elaboração de projetos, construção, fornecimento de equipamentos, respectiva montagem e entrega em condições de operar.

\subsection{A importância do Contrato de EPC para o financiamento do projeto}

Tendo em vista que os contratantes dos maiores empreendimentos, principalmente os de infraestrutura, têm recorrido à estruturação financeira

\footnotetext{
${ }^{4}$ ENEI, José Virgílio Lopes. Project Finance. São Paulo: SARAIVA, 2007. p. 32.
} 
na modalidade project finance, julga-se importante falar sobre os principais aspectos deste modelo de financiamento que facilitou a entrada do capital privado nos grandes projetos de engenharia, e, sem dúvidas, permitiu que tais empreendimentos pudessem ser financeiramente viáveis com reduzido impacto para os empreendedores.

Essa forma de financiamento surgiu no Reino Unido, no início da década de 70, em virtude da expansão de suas plataformas continentais de exploração de petróleo e gás. Por conta dos investimentos intensivos necessários e dos elevados riscos associados à atividade de exploração e produção de petróleo e gás natural, os empreendedores e financiadores buscaram alternativas inovadoras de financiamento, a partir do isolamento dos riscos, surgindo, como melhor opção, o que mais tarde passou-se a chamar project finance. ${ }^{5}$

No Brasil, o project finance surgiu na década de 90 , no contexto das privatizações, em que o Estado vendeu o controle de mais de uma centena empresas e concessionárias de serviços públicos. Em virtude da multiplicidade de oportunidades e dos altos investimentos que se tornavam necessários pelo setor privado, as empresas vencedoras das licitações buscaram novas formas de financiamento que permitissem desonerar seu patrimônio, buscando restringir as garantias do financiamento aos recebíveis do projeto.

O project finance apresentou-se como boa alternativa naquele contexto, pois os credores poderiam repartir os riscos do negócio com os devedores de modo que o isolamento e alocação de riscos poderia ser dimensionado para quem melhor poderia mitigá-los. Ou seja, cada

\footnotetext{
${ }^{5}$ BONOMI, Cláudio A.; MALVESSI, Oscar. Op. cit., p. 64.
} 
investidor poderia escolher a parcela de risco que the fosse mais aceita, recebendo, em contrapartida, o retorno proporcional a ele. ${ }^{6}$

Feita uma breve introdução quanto ao surgimento desta forma sofisticada de financiamento no Brasil, relevante falar também sobre suas principais características, bem como a importância que o Contrato de EPC possui para captar o investimento necessário para a viabilidade de um projeto.

No contexto do project finance é usual a constituição de uma sociedade de propósito específico (SPE) para suportar os riscos atribuídos ao próprio empreendedor, e para apropriar custos, receitas, e etc., de forma a segregar o empreendimento dos empreendedores. Trata-se de uma blindagem dos seus sócios/acionistas quanto ao risco do empreendimento, visto que a nova empresa funcionaria como uma espécie de "patrimônio de afetação", circunscrevendo o comprometimento financeiro de seus sócios. ${ }^{7}$

Quanto às partes que participam do empreendimento e da estruturação do project finance, ou os usualmente chamados players, podem ser destacados: (i) os sponsors, também designados aqui empreendedores ou proprietários, que têm a seu cargo a implementação do projeto e são os acionistas da SPE do empreendimento; (ii) os lenders ou financiadores que são os bancos e os demais agentes financiadores que fornecem a maior parte dos recursos ao empreendimento; (iii) os construtores, fabricantes, operadores, seguradoras, fornecedores de insumos e demais terceiros relevantes cuja participação seja crucial ao sucesso do empreendimento; (iv) advogados, assessores e contadores, que concedem o suporte legal à confecção e execução dos contratos, e até mesmo (v) o Estado, já que a

\footnotetext{
${ }^{6}$ Ibid.

${ }^{7}$ ROCHA, João Luiz C. da. O moderno contrato de empreitada global. Valor Econômico. Disponível em: <http://www.lexlegis.com.br/leitor_oficial/n1700/o-moderno-contrato.htm> Acesso em: 14 dez. 2010.
} 
maioria dos empreendimentos envolve serviços ou ativos públicos, como, por exemplo, telefonia, estradas, energia, e etc.

Existem projetos em que os riscos econômicos, técnicos, ambientais ou decorrentes de regulamentação (riscos legais) são de tal magnitude que seria impraticável ou imprudente que uma única parte os assumisse isoladamente.

Assim, a justa alocação dos riscos nos diversos instrumentos contratuais que dão suporte ao projeto será condição fundamental para o sucesso deste tipo de financiamento aplicado às grandes obras. Isso porque, caso ocorra algum evento que venha a materializar um relevante risco inerente ou relativo ao projeto, certamente tal evento afetará a capacidade de pagamento do tomador do empréstimo.

Nesse caso, o financiador poderá, dependendo do instrumento do financiamento, assumir o controle operacional do projeto, sem que tal interfira na operação dos demais negócios do empreendedor. Assim se pronuncia JOSÉ EMILIO NUNES PINTO sobre o tema:

"é importante que aludidos contratos outorguem direitos aos financiadores de ingressar no projeto ou no controle operacional deste, exercendo os direitos e as obrigações assumidas originalmente pelo tomador, de forma a evitar ou sanear eventos que possam afetar a consistência estabilidade do fluxo de caixa e, no limite, de assegurar a suficiência de fundos para o cumprimento das obrigações decorrentes do financiamento."

Ademais, um grande fator que justifica a adoção do project finance é que os sponsors não têm seus balanços patrimoniais onerados pelo endividamento, na medida em que estas podem dar como garantia do retorno do investimento os próprios ativos e recebíveis do projeto, o seja, a receita da SPE. Em outras palavras, o valor dos ativos incorporados ao

\footnotetext{
${ }^{8}$ PINTO, José Emílio Nunes. O Contrato de EPC para construção de grandes obras de engenharia e o novo Código Civil. Revista da AARJ, Volume III, em Janeiro de 2003. p. 72.
} 
projeto em si não é o principal foco da atenção dos financiadores, mas sim, a capacidade daqueles ativos gerarem futuras receitas em decorrência da operação do projeto. ${ }^{9}$

Isso amplia o fôlego das empresas para tomar novos empréstimos e, consequentemente, contribui para a consolidação dos projetos de infraestrutura em andamento no país, eis que tais projetos são visivelmente dependentes de altos investimentos.

Com base no exposto, é possível afirmar que o Contrato de EPC é uma peça extremamente importante para a estruturação de um project finance na medida em que (i) assegura a previsibilidade do investimento, apresentando preço e prazos definidos para um determinado escopo e (ii) equilibra os riscos associados à construção, vez que o consórcio construtor assume responsabilidade integral sobre os riscos de engenharia, suportando, portanto, problemas de toda a grandeza, inclusive aqueles que envolvem aspectos topográficos, de qualidade do solo e etc.

\subsection{Os elementos subjetivos do Contrato de EPC (O "Epecista" e o contratante)}

Nos Contratos de EPC o empreendedor contrata um empreiteiro, para desenvolver as obrigações de construção, contratação de fornecedores, transporte, montagem e instalações do projeto. Esse empreiteiro, de acordo com o jargão do setor, é chamado de "Epecista". Pode-se dizer que os Contratos de EPC contemplam diversas relações jurídicas entre o contratante e o Epecista, uma vez que este desempenha diferentes papéis no contexto da execução do contrato.

\footnotetext{
${ }^{9}$ Ibid.
} 
O Epecista é engenheiro quando elabora os projetos básico e detalhado de engenharia, é montador quando tiver a função de proceder a montagem e comissionamento da obra em si, assim como será tratado como fornecedor de equipamentos quando o instrumento contratual tiver como objeto o desenho, projeto, construção, fornecimento e montagem de equipamentos, comissionamento da obra e teste de desempenho. ${ }^{10}$

Grande parte dos recentes Contratos de EPC, até pela sua magnitude, agregam duas ou mais empresas Epecistas para a cobertura total do objeto. Em regra, estas empresas atuam solidariamente jungidas na responsabilidade total perante o contratante, independentemente de suas alocações específicas a qual parte do projeto total lhes caiba por especialidade. Nestas hipóteses cuida-se muito da formação de consórcios, não raramente um consórcio internacional. ${ }^{11}$

O Epecista, através do consórcio constituído nos termos da Lei $n^{\mathbf{o}}$ 6.404 de 15 de dezembro de 1976, contratará materiais e serviços junto a empresas especializadas. A necessidade de contratação através do consórcio de empresas ocorre pois dificilmente um único contratado será capaz de concentrar todas essas atividades verticalizadas relacionadas a um empreendimento. Quanto mais sofisticado for o escopo da obra, mais expertise em diferentes assuntos o contratado deverá ter.

Diante do exposto, os Contratos de EPC normalmente envolvem muitas partes, como, por exemplo, os sócios empreendedores e os membros dos consórcios construtores, que, por sua vez, incluem empreiteira de obras civis, fabricantes de equipamentos, empresa montadora de equipamentos e empresa projetista. Quanto a estas, embora contratadas para a execução de objetos distintos, importante será a atuação de forma integrada, resultando

\footnotetext{
${ }^{10}$ Ibid.

${ }^{11}$ ROCHA, João Luiz C. da. Op. cit.
} 
num conjunto produtivo ordenado e útil para a consecução do empreendimento.

Tendo em vista a complexidade das relações que se formam no âmbito do Contrato de EPC, o fechamento da redação de suas cláusulas contratuais dependerá de longas etapas de negociações entre as diversas áreas de todas as empresas envolvidas na negociação, tais como jurídica, comercial e de engenharia. Eventualmente, determinada cláusula que venha a ser exigida por determinada empresa poderá ser inaceitável pela outra, o que contribuirá ainda mais para o alongamento do prazo de discussão do contrato.

Uma vez que o projeto deve seguir um cronograma em que, inevitavelmente, todas as partes estão submetidas, e em que o início de uma etapa exige a conclusão de uma etapa anterior por terceiro fornecedor, a dificuldade com que se defrontam os que estejam envolvidos em operações dessa natureza é justamente harmonizar cláusulas, direitos e obrigações contidos em diversos instrumentos contratuais, inclusive dos que não sejam partes contratantes.

Pode-se afirmar que o Contrato de EPC é marcado pela complexidade das relações jurídicas entre as partes contratantes, pelos diversos papéis que estas desempenham ao longo do prazo de vigência do contrato e pela intervenção de terceiros. Ademais, na medida em que o Contrato de EPC visa estipular as regras destinadas a regular tais relações complexas, é fundamental que seja redigido de maneira minuciosa e detalhada, visando sempre harmonizar os diversos interesses envolvidos da maneira mais clara possível. 


\subsection{O Contrato de EPC Turnkey Lump Sum}

Conforme se falará no próximo capítulo, o Contrato de EPC parece muito se assemelhar ao que se convencionou denominar regime de empreitada, previsto no Código Civil brasileiro, nos artigos 601 a 626. A empreitada global se caracteriza por ser de preço certo, data determinada de conclusão e chave na mão, caso em que o contratante recebe a obra em plenas condições de operar a instalação.

No mesmo sentido, o Contrato de EPC acerta um "pacote fechado" de obrigações por parte do contratado que, no limite do preço global, deverá entregar a obra pronta e prestes a funcionar. No setor privado, em que o prazo de finalização e a qualidade dos recursos empregados nos empreendimentos são de suma importância, o Contrato de EPC, em sua aplicação mais usual, o ocorre na modalidade Turnkey Lump Sum.

O método do Turnkey, cuja expressão significa "chave na mão", designa a extensão do escopo da empresa contratada, a quem fica atribuída a responsabilidade por entregar o empreendimento ao contratante pronto para operação. Nesta modalidade o consórcio construtor assume a responsabilidade pelo desenvolvimento do projeto, execução das obras civis, fabricação, fornecimento e montagem dos equipamentos, bem como pelo comissionamento e testes.

Feita uma breve introdução quanto às características do Contrato de EPC na modalidade TurnKey, resta falar também da maneira mais adotada pelas práticas do mercado para calcular ou expressar o preço de um contrato de grande obra de engenharia.

Em muitos desses contratos, a fixação do preço está fundada em um procedimento denominado open book. Por aplicação desse procedimento, o 
dono da obra tem acesso aos custos e margens incorridos pelo empreiteiro, os quais são levados em consideração para a fixação do valor da obra. Para isso, é usual que seja contratado um auditor independente para fiscalizar o que de fato está sendo gasto pelo Epecista.

Contudo, do ponto de vista do financiador do empreendimento, é muito mais interessante e seguro a adoção da forma de remuneração na modalidade Lump Sum, que nada mais é que o preço global previamente fixado levando em conta o montante que será despendido para a consecução de todas as etapas do empreendimento.

Esta modalidade possui como característica o pleno conhecimento do escopo dos serviços, requerendo uma análise cuidadosa de todos os documentos relacionados (desenhos, dados, cronogramas), de modo que haja uma maior precisão dos custos que serão considerados para a fixação do Lump Sum. Além disso, os riscos conscientes e deliberadamente assumidos pelo Epecista refletem diretamente no preço global do contrato, que será mais caro na medida em que não há como prever se ocorrerá, ou não, a materialização de tais riscos.

Embora se possa dizer que um determinado Epecista tenha expertise para construção, por exemplo, de uma plataforma de petróleo, e que, portanto, não deveria ocorrer aumento do preço já que ele já sabe dos riscos inerentes ao negócio, não restam dúvidas de que a construção de cada empreendimento vai acarretar riscos das mais variadas formas, e que não necessariamente se repetem.

Como exemplo, pode-se citar que as condições climáticas de um determinado estado em que se localiza um terreno pra a construção de uma plataforma poderá impactar diretamente nos custos do negócio, demonstrando assim um risco que é suportado e deve ser levado em 
consideração pelo Epecista. $\mathrm{O}$ aumento repentino e fora das curvas históricas dos volumes pluviométricos pode interferir na obra, bem como impacta a condição das marés no momento em que se faz o load-out da plataforma, (i.e. a movimentação desta para começar a operar no mar). Condições adversas geram impacto significativo de prazo e preço, além de eventualmente gerar quebra de máquinas e acidentes.

Por fim, como forma de pagamento, as partes deverão estipular se o preço será pago em parcelas mensais, mediante o cumprimento de marcos intermediários, ou de outra forma mais conveniente às partes e à execução do objeto do contrato.

Tendo em vista as modalidades que são adotadas para fixar a extensão do escopo e o preço do Contrato de EPC, pode-se afirmar que se o projeto é financiado através do project finance, em que o próprio projeto é a garantia do empréstimo tomado, é provável que os agentes financiadores irão exigir a utilização de Contratos de EPC do tipo Turnkey Lump Sum, com vistas a minimizar o risco de não receber de volta o pagamento do empréstimo.

Sobre o tema, vejam-se as palavras de LUIZ ALBERTO GÓMEZ:

\begin{abstract}
"Do ponto de vista do contratante e dos financiadores, a forma de contratação de preço global fixo é a ideal, já que requer um mínimo de provisões para eventuais variações e reivindicações. A quantidade a ser gasta é definida com antecedência e dá a contratada o maior incentivo para completar o trabalho no prazo e reduz a um mínimo os custos de administração do contrato. Esses benefícios, porém, só podem ser obtidos se a contratada apresentou uma proposta realista." 12
\end{abstract}

Não obstante os preços do Contrato de EPC Turnkey Lump Sum tendam a ser superiores aos contratos em que os preços são calculados por cada atividade que efetivamente foi desempenhada durante o período compreendido na medição, dada a necessidade de cobertura para o risco ao

\footnotetext{
${ }^{12}$ GÓMEZ, Luis Alberto. Contratos Epc Turn Key. São Paulo: Visual Books, 2006, p. 32.
} 
qual se expõe o consórcio construtor, ao que parece, contratos desta natureza tornar-se-ão uma constante em projetos de grande porte.

Notório, portanto, que os Contratos de EPC Turnkey Lump Sum são muito bem vistos por investidores e credores na medida em que transferem ou, ao menos, mitigam o risco de construção, compartilhando-o com entidades que, por definição, têm maiores condições ou grau de especialização para assumi-los. 


\title{
Capítulo II
}

\section{PRINCÍPIOS E CLASSIFICAÇÕES DOS CONTRATOS}

Sumário: 2.1. Definição e Princípios fundamentais dos contratos; 2.1.1. Princípio da autonomia da vontade das partes e o Princípio da função social do contrato; 2.1.2. Princípio da força obrigatória dos contratos e o Princípio da relatividade; 2.1.3. Princípio da boafé nos contratos; 2.2. Classificação dos contratos (típicos e atípicos); 2.3. O contrato de empreitada.

\subsection{Definição e Princípios fundamentais dos Contratos}

O Código Civil de 2002 conceitua todas as figuras contratuais, ao passo que não define o conceito de contrato. A doutrina, por sua vez, é pacífica em conceituar o contrato como um negócio jurídico bilateral ou plurilateral que visa à criação, modificação ou extinção de direitos e deveres com conteúdo patrimonial. ${ }^{13}$

O contrato nasceu a partir do momento em que as pessoas passaram a se relacionar e a viver em sociedade. Nesse sentido, CAIO MARIO diz que:

\begin{abstract}
"O mundo moderno é o mundo do contrato. E a vida moderna o é também, e em tão alta escala que, se se fizesse abstração por um momento do fenômeno contratual na civilização de nosso tempo, a consequência seria a estagnação da vida social. O "homo aeconomicus" estancaria as suas atividades. É o contrato que proporciona a subsistência de toda a gente. Sem ele, a vida individual regrediria e a atividade do homem limitar-se-ia aos momentos primários." ${ }^{\text {.14 }}$
\end{abstract}

Diante da evolução da sociedade brasileira e das profundas alterações pelas quais vem passando o instituto pode-se apontar também um conceito pós-moderno de contrato que reconhece o contrato inserido no meio social e a influência que este exerce na vida das pessoas.

\footnotetext{
${ }^{13}$ TARTUCE, Flávio. Direito civil - teoria geral dos contratos e contratos em espécie. $3^{\mathrm{a}}$ ed. São Paulo: Método, 2008. p. 28.

${ }^{14}$ PEREIRA, Caio Mário da Silva. Instituições de Direito Civil, vol. III. 11ª ed. Rio de Janeiro: Forense, 2004. p. 11.
} 
PAULO NALIM propõe o conceito pós-moderno de contrato da seguinte maneira:

"É a relação jurídica subjetiva, nucleada na solidariedade constitucional, destinada a produção de efeitos jurídicos existenciais e patrimoniais, não só entre os titulares subjetivos da relação, como também perante terceiros." ${ }^{\text {.15 }}$

Olhando para o futuro, e porque não já para o presente, é de se concordar com esse conceito. Primeiro porque o contrato está amparado em valores constitucionais. Segundo porque envolve também situações existenciais das partes contratantes. Terceiro porque o contrato pode gerar efeitos perante terceiros, e não somente entre as partes contratantes. ${ }^{16}$

Feita a análise quanto ao conceito do contrato, bem como sua acepção moderna, resta oportuno falar dos princípios fundamentais que devem ser observados quando da elaboração de um Contrato de EPC, tais como: princípio da autonomia da vontade das partes, princípio da função social do contrato, princípio da força obrigatória dos contratos, princípio da relatividade e o princípio da boa-fé nos contratos.

\subsubsection{O Princípio da autonomia da vontade das partes e o Princípio da função social do contrato}

O princípio da autonomia da vontade consiste no poder dos contratantes de estipular livremente, da maneira mais conveniente e mediante acordo de vontades, a disciplina de seus interesses, suscitando assim efeitos tutelados pela ordem jurídica. ${ }^{17}$

\footnotetext{
${ }^{15}$ NALIM, Paulo. Do contrato - conceito pós moderno. $1^{\text {a }}$ ed. $5^{\text {a }}$ tir. Curitiba: Juruá, 2005. p. 225.

16 TARTUCE, Flávio. Op. cit., p. 29.

${ }^{17}$ DINIZ, Maria Helena. Teoria das obrigações contratuais e extracontratuais. 18 ${ }^{\mathrm{a}}$ ed., V. 3, Ex. 6, São Paulo: Saraiva, 2003. p. 32.
} 
Baseado neste princípio, no âmbito do Contrato de EPC, contratante e Epecista poderão estipular livremente as regras do contrato que dá suporte ao projeto. Até porque, como se falará mais adiante, o contrato de empreitada tipificado no Código Civil brasileiro não é suficiente para estruturar esse tipo de contrato, sendo preciso, portanto, as partes "construírem" um instrumento que reflita todos os interesses envolvidos.

A liberdade de contratar está estritamente ligada ao princípio da autonomia da vontade, abrangendo os poderes de auto-regência de interesses, de livre discussão das condições contratuais e, por fim, de escolha do tipo de contrato conveniente à atuação da vontade. Manifesta-se sob três principais aspectos: a liberdade de contratar propriamente dita, a liberdade de estipular o contrato e a liberdade de estipular o conteúdo do contrato. $^{18}$

Por outro lado, a autonomia da vontade não é ilimitada ou absoluta, pois esbarra na supremacia da ordem pública que vem a vedar estipulações que lhes sejam contrárias ou contrárias aos bons costumes. Assim, o princípio da função social do contrato, previsto no artigo 421 do Código Civil, deverá prevalecer quando tal autonomia estiver em confronto com o interesse social. $^{19}$

A lei não define o que vem a ser função social do contrato, podendo esta locução ser interpretada das mais diversas formas, conduzindo à declaração de nulidades de cláusulas ou até mesmo de toda a avença. Nesse sentido, MARIA HELENA DINIZ ensina que:

\footnotetext{
"A liberdade de contratar é reconhecida, mas seu exercício está condicionado à função social do contrato e implica valores de boa-fé e probidade (CC, art. 422). Logo, a função social do contrato não elimina o princípio da autonomia contratual, mas atenua ou reduz seu alcance, quando estiverem presentes
}

\footnotetext{
${ }^{18}$ GOMES, Orlando. Contratos. $18^{\mathrm{a}}$ ed. Rio de Janeiro: Forense, 1999. p. 22.

${ }^{19}$ PEREIRA, Caio Mário da Silva. Op. cit., p. 13.
} 
interesses meta-individuais ou interesse individual coletivo relativo à dignidade da pessoa humana." ${ }^{20}$

No âmbito do Contrato de EPC, muito embora as partes tenham plena liberdade de estipular cláusulas e condições que lhes são mais convenientes, tendo em mente o princípio da função social do contrato, sob nenhuma hipótese os interesses do contratante e do Epecista poderão lesar interesses considerados de maior relevância para a sociedade.

Cite-se como exemplo a construção de uma usina hidrelétrica em área de preservação ambiental. Por mais benefícios econômicos que aquela usina possa trazer para uma população, deve-se sopesar se não se trata de uma ameaça à fauna ou determinada espécie, causando danos irreversíveis ao meio ambiente. Por se tratar de um princípio que envolve matéria constitucional, este deverá prevalecer sobre qualquer interesse buscado pelas partes.

Igualmente, não poderá o Contrato de EPC prever o descarte de materiais utilizados na execução das obras ou a captação de águas sem atentar para as regras que regem, respectivamente, o depósito e descarte de resíduos e a utilização dos recursos hídricos.

Conclui-se, portanto, que o contrato não é mais visto pelo prisma individualista de utilidade para os contratantes, mas é visto no sentido social, de utilidade para a comunidade, podendo ser coibido o contrato que não busque essa finalidade. ${ }^{21}$

$\mathrm{Na}$ medida em que as partes podem estipular livremente o contrato, ajustando-o da maneira mais conveniente, é razoável que ocorram restrições trazidas pelo dirigismo contratual, que é a intervenção do Estado na

\footnotetext{
${ }^{20}$ DINIZ, Maria Helena. Op. cit., p. 34.

${ }^{21}$ VENOSA, Silvio de Salvo. Direito Civil - teoria geral das obrigações e teoria geral dos contratos. $3^{\text {a }}$ ed. V. 2, EX. 5, São Paulo: Atlas, 2003. p. 376.
} 
economia do negócio jurídico contratual. Se assim não fosse, se nada pudesse ser feito para sanar uma situação visivelmente desfavorável a uma das partes, a ordem jurídica não estaria cumprindo sua função de assegurar a igualdade econômica entre as partes.

\subsubsection{Princípio da força obrigatória dos contratos e o Princípio da relatividade}

Um contrato válido e eficaz deve ser cumprido pelas partes e essa obrigatoriedade forma a base do direito contratual. Trata-se, portanto, do chamado princípio da força obrigatória dos contratos, cujo brocardo é a tradução livre do latim pacta sunt servanda, que se consubstancia na regra de que o contrato é lei entre as partes.

Se assim não fosse, se o contrato não tivesse tal força obrigatória, certamente estaria estabelecido o caos do convívio em sociedade, pois dificilmente haveria a certeza de que uma avença seria respeitada pelas partes. $^{22}$

Vale ressaltar que dentro da realidade jurídica e fática do mundo pósmoderno, o princípio da força obrigatória dos contratos continua previsto no ordenamento jurídico brasileiro, porém, deve ser relativizado naquelas situações em que se divisar conflito com o cumprimento da função social do contrato, caso em que mais uma vez, este último princípio deverá prevalecer sob qualquer hipótese.

Além disso, o ato negocial, que possui força obrigatória entre as partes, em regra somente produz efeitos entre os contratantes, não podendo prejudicar e nem aproveitar terceiros. Essa lógica decorre do fato de que se

${ }^{22}$ Ibid. 
o acordo deriva da vontade intrínseca das partes, logo, ninguém se submeterá a tais atos negociais, a não ser que a lei o imponha ou a própria pessoa o queira.

Esse é o chamado princípio da relatividade dos contratos. Realmente, se, de um lado, nenhum terceiro pode ser vinculado a um ato negocial no qual não anuiu, por outro lado, a existência de um contrato produz efeitos no meio social, repercutindo em face de terceiros, que deles não podem escapar por força de lei ou da vontade das partes. ${ }^{23}$

O Contrato de EPC, contudo, é preparado pelas partes antecipando eventual intervenção de terceiros, normalmente, por força de obrigações assumidas em outros instrumentos. É o que ocorre quando há cessão de garantias. $^{24}$

Utiliza-se, ainda, o exemplo do empreiteiro que descumpre com a obrigação de entregar o projeto livre de quaisquer vícios ou defeitos. Poderia o contratante, neste caso, buscar terceiro que o fizesse, lançando mão da garantia para cobrir o custo associado ao inadimplemento do empreiteiro.

Pode-se citar também a hipótese em que o financiador do empreendimento ingressa no controle operacional do projeto (step-in), nos termos das cláusulas previstas no contrato, caso o contratante sofra algum risco que, devido a sua relevância, possa afetar a sua capacidade de pagamento das obrigações relacionadas ao financiamento.

\footnotetext{
${ }^{23}$ DINIZ, Maria Helena. Op. cit., p. 106.

${ }^{24}$ PINTO, José Emílio Nunes. Op. cit., p. 95.
} 


\subsubsection{Princípio da boa-fé nos contratos}

O Código Civil de 2002 inovou ao prever o princípio da boa-fé contratual introduzido eu seu artigo 422. Apesar de ser aplicado muito mais no âmbito da interpretação de um contrato, esse princípio consagrou objetivamente a necessidade de as partes manterem a conduta de probidade e lealdade durante todas as fases, quais sejam: fase pré-contratual, durante a execução do contrato, bem como ao término deste.

O princípio da boa-fé assegura que, no âmbito da interpretação, o sentido literal da linguagem formalizada no contrato não deve prevalecer sobre a intenção manifestada na declaração de vontade das partes, sob pena de afetar a segurança das relações jurídicas. Ademais, aventa-se a ideia de que, entre as partes do contrato, deve haver colaboração para a boa execução do mesmo, incluindo mútuo auxílio na formação e execução do contrato, impedindo que uma dificulte a ação da outra.

Diante da não previsão do Contrato de EPC no Código Civil brasileiro, para que haja segurança jurídica do cumprimento daquilo que está sendo celebrado entre as partes, o princípio da boa-fé deve ser rigorosamente aplicado a esta modalidade de contratação.

Não é a toa que em muitos destes contratos é possível encontrar uma cláusula estipulando que as partes se comprometerão a envidar seus melhores esforços para resolver amigavelmente e de boa-fé as divergências e outras questões relativas ao objeto do contrato, tão logo quanto possível, através de negociação direta. Como última alternativa, caso não haja êxito na negociação, as partes poderão recorrer a outras formas de solução de litígio, como a arbitragem, por exemplo. 


\subsection{Classificação dos contratos (típicos e atípicos)}

Existe um maior interesse prático do que meramente teórico no que tange à classificação dos contratos a partir de suas respectivas características e natureza.

A classificação de um contrato influenciará diretamente na análise da regra que lhe é aplicável, servindo para posicionar corretamente o negócio jurídico no âmbito do seu adimplemento ou inadimplemento. Dependendo da espécie do contrato sob exame, haverá distintas formas de interpretação das partes e do objeto contratado, bem como haverá distintos efeitos no caso concreto.

Ilustrativamente falando, da mesma forma que um médico procura definir determinado fenômeno no corpo humano de um paciente, de modo que todos os conhecedores da ciência médica imediatamente o situem no universo da Medicina, assim o faz o jurista em relação ao Direito. Quando o jurista fixa a natureza jurídica de um contrato, está "diagnosticando-o", procurando assim chegar com mais facilidade à solução dos problemas emergentes do negócio sob exame, quer na elaboração do contrato, quer na avaliação de suas consequências. ${ }^{25}$

O exercício da classificação dos contratos é um trabalho eminentemente doutrinário, não cabendo ao legislador definir as classes gerais dos contratos, sob pena de tolher o dinamismo do direito contratual. A doutrina, por sua vez, busca facilitar o trabalho do intérprete, agrupando os contratos em diversas categorias, com identidades e afinidades, porque daí decorrerão raciocínios e regras de interpretação idênticas ou semelhantes.

\footnotetext{
${ }^{25}$ VENOSA, Silvio de Salvo. Op. cit., p. 390.
} 
São muitas as classificações atribuídas pela doutrina em função de vários fatores. Conforme distintos critérios, os contratos são classificados como consensuais e reais; solenes e não solenes; principais e acessórios; instantâneos e de duração; de execução imediata e de execução diferida; típicos e atípicos; pessoais e impessoais; civis e mercantis; individuais e coletivos; e causais e abstratos. $^{26}$

No que tange ao Contrato de EPC, interessante é a análise deste contrato em relação à sua designação sob a ótica dos contratos típicos e atípicos.

$\mathrm{O}$ contrato típico ou nominado refere-se àqueles esquematizados na lei, com denominação própria, formando espécies definidas de contratos. Inserem-se numa figura que tem disciplina legal, pois recebe da ordem jurídica uma regulamentação. O Código Civil de 2002 rege e esquematiza vinte e três tipos dessa espécie de contrato, podendo-se citar como exemplo o contrato de compra e venda, troca, doação, locação de coisas, empréstimo, prestação de serviços, mandato, empreitada e etc.

Sobre os contratos típicos, ORLANDO GOMES diz:

\footnotetext{
"As relações econômicas habituais tratam-se sob as formas jurídicas que, por sua frequência, acabam adquirindo tipicidade. As espécies mais comuns são objeto de regulamentação legal, configurando-se por traços inconfundíveis e individualizando-se por denominação específica." ${ }^{27}$
}

Por outro lado, é facultado ao sujeito de direito criar mediante vínculo contratual qualquer tipo de obrigação, desde que de acordo com a ordem jurídica e os bons costumes. Além disso, como já dito no Capitulo I, a sociedade prescreve a necessidade de novos modelos de realização do

\footnotetext{
${ }^{26}$ GOMES, Orlando. Op. cit., p. 70.

${ }^{27}$ Ibid. p. 102.
} 
direito, o que inclui novos modelos contratuais, para atender aos interesses privados que evoluem junto com as novas dinâmicas sociais.

Daí, à margem dos paradigmas estabelecidos, surgem os contratos atípicos, conforme sabiamente expõe NUNES PINTO:

"A existência de contratos atípicos, em nosso direito, visa atender ao dinamismo das relações em sociedade, especialmente as de natureza econômica. Não pode a legislação tipificar todos os tipos de contratos, especialmente porque, ao longo da vigência da lei, surgem relações jurídicas novas. Por outro lado, há que se ter em mente que o mundo jurídico não poderá ignorar a existência da realidade dos fatos, nem mesmo dos instrumentos que o regem.. ${ }^{28}$

Os contratos atípicos formam-se de elementos originais ou resultam da fusão de elementos próprios de outros contratos. Ordenados a atender interesses não disciplinados especificamente na lei, os contratos atípicos caracterizam-se pela originalidade, constituindo-se, não raro, pela modificação de elementos característicos de contratos típicos, desfigurandose dando lugar a novos contratos. Outras vezes, pela eliminação de elementos secundários de um contrato típico. Dividem-se em contratos atípicos propriamente ditos e contratos atípicos mistos. ${ }^{29}$

Quanto ao último, trata-se de contrato formado por institutos provenientes de diferentes tipos contratuais, como assinala ORLANDO GOMES:

\footnotetext{
"Os contratos mistos compõem-se de prestações típicas de outros contratos, ou de elementos mais simples, combinados pelas partes. (...) O problema dos contratos mistos consiste fundamentalmente na determinação de sua disciplina jurídica. Não tendo regulamentação legal específica, é preciso saber que regras lhes são aplicáveis, além, naturalmente, dos princípios gerais de Direito Contratual. Três soluções dividem a preferência dos escritores: 1a) a da combinação; 2a) a da absorção; 3a) a da aplicação analógica." ${ }^{30}$
}

\footnotetext{
${ }^{28}$ PINTO, José Emílio Nunes. Op. cit., p. 95.

${ }^{29}$ GOMES, Orlando. Op. cit., p. 103.

${ }^{30}$ Ibid. p. 106.
} 
A própria dinâmica da vida dos homens e a realidade jurídica que os acompanha apontam necessidade e urgência de uma releitura contratual, que pode ser considerada saudável na medida em que, para a sociedade, é interessante que as instituições sejam renovadas, e não "engessadas" ao ponto de se tornarem ineficazes na prática.

Pode-se concluir que os contratos atípicos surgem diante desses interesses novos, oriundos da crescente complexidade da vida econômica, reclamando disciplina uniforme em que as próprias partes estabelecem livremente, sem terem regras objetivas a serem observadas. Como será analisado adiante, esse é justamente o caso do surgimento e consolidação da utilização dos Contratos de EPC em nossa atual realidade.

\subsection{O contrato de empreitada}

Com a globalização, vários institutos jurídicos passaram a se cotejar e influenciar mutuamente mais de perto. No caso dos contratos, as ordens jurídicas que se achavam mais avançadas exportaram para outros lugares institutos obrigacionais que refletiam maior complexidade e sofisticação nas suas teias de responsabilidades e obrigações. ${ }^{31}$

Assim aconteceu no Brasil com os Contratos de EPC, que guardam, à luz do direito pátrio vigente, pontos em comum com os contratos de empreitada global, sendo de ressaltar que algumas das cláusulas padrão dos Contratos de EPC encontram tratamento legal nas disposições dos contratos de empreitada contidas no Código Civil vigente. ${ }^{32}$

\footnotetext{
${ }^{31}$ ROCHA, João Luiz C. da. Op. cit.

${ }^{32}$ PINTO, José Emílio Nunes. Op. cit., p. 71.
} 
Assim, julga-se importante tratar das características do contrato de empreitada, para que, em seguida, seja possível uma comparação de suas disposições com aquelas normalmente convencionadas nos Contratos de EPC, de origem anglo-saxã.

A empreitada está tipificada no ordenamento jurídico brasileiro nos artigos 610 a 626 do Código Civil de 2002. Trata-se de um contrato mediante o qual uma das partes (o empreiteiro) se obriga a realizar uma obra específica, pessoalmente ou por intermédio de terceiros, cobrando uma remuneração a ser paga pela outra parte (dono da obra), sem vínculo de subordinação. $^{33}$

Quanto às suas características, este é um contrato bilateral, pois gera obrigação para ambas as partes; é consensual na medida em que se conclui mediante acordo de vontade entre as partes; é oneroso, pois ambas as partes têm benefícios correspondentes aos respectivos sacrifícios, e por fim, não é um contrato solene, visto que não se exige formalidades específicas para a sua contratação.

Nos termos do artigo 610 do Código Civil, são consideradas duas espécies de empreitada: a empreitada somente de mão de obra (lavor) ou a empreitada mista, que além da mão de obra, o empreiteiro deverá fornecer também os materiais que serão utilizados. Frise-se que a obrigação de fornecer os materiais e entregá-los no local da obra não se presume, devendo, portanto, resultar da lei ou da vontade das partes.

É comum a ocorrência de alguns ônus que podem advir quando da entrega dos materiais, os quais precisarão ser levados em conta na negociação do contrato de empreitada. Isso se deve ao fato de que o artigo 611 do Código Civil estabelece que os riscos correrão por conta do

\footnotetext{
${ }^{33}$ PEREIRA, Caio Mário da Silva. Op. cit., p. 315.
} 
empreiteiro até o momento da entrega da obra, caso este forneça os materiais. Por outro lado, caso o empreiteiro só forneça mão de obra, todos os riscos em que não tiver culpa correrão por conta do dono da obra.

Quanto ao modo de fixação do preço ou da remuneração, prevê o artigo 614 do Código Civil que a empreitada poderá ocorrer por medida, em que a execução do serviço é pactuada pelo empreiteiro e pelo dono da obra em partes. Cabe ressaltar que o preço da empreitada também poderá ser estipulado para a obra inteira, por preço global, não se levando em conta o fracionamento da atividade desenvolvida pelo empreiteiro ou o resultado da mesma.

Destaque-se que antes que seja feito o pagamento, é importante que seja devidamente dimensionado e examinado o que está sendo pago, pois, de acordo com o artigo 614, parágrafo $1^{\circ}$ do Código Civil, tudo o que se pagou presume-se verificado. Além disso, nos termos do mesmo artigo, parágrafo $2^{\circ}$, o que se mediu presume-se verificado, se, em trinta dias, a contar da medição, não forem denunciados os vícios ou defeitos pelo dono da obra ou por quem estiver incumbido da sua fiscalização.

Ademais, por determinação do artigo 615 do Código Civil, concluída a obra de acordo com o ajuste, ou o costume do lugar, o dono é obrigado a recebê-la. Contudo, esta obrigação, não é absoluta, pois se o empreiteiro se afastou das instruções recebidas ou das regras técnicas, poderá o proprietário rejeitá-la, ou exigir abatimento no preço.

Importante característica quanto ao recebimento da empreitada é a garantia quinquenal prevista no artigo 618 do Código Civil. De acordo com este, o empreiteiro de materiais e execução responderá, durante o prazo irredutível de 5 (cinco) anos pela solidez e segurança do trabalho, tanto em razão dos materiais, quanto do solo. É oportuno lembrar que decairá o 
direito assegurado neste artigo para o dono da obra que não propuser a ação contra o empreiteiro, nos 180 (cento e oitenta) dias seguintes ao aparecimento do vício ou defeito.

De acordo com o artigo 619 do Código Civil, salvo estipulação em contrário, o empreiteiro que for incumbido de executar uma obra, segundo plano aceito por quem a encomendou, não terá direito a exigir acréscimo no preço, ainda que sejam introduzidas modificações no projeto, salvo casos em que estas resultem de instruções escritas do dono da obra. Entretanto, ainda que não tenha havido autorização escrita, o dono da obra é obrigado a pagar ao empreiteiro os aumentos e acréscimos, segundo o que for arbitrado, se, sempre presente à obra, por continuadas visitas, não podia ignorar o que se estava passando, e nunca protestou.

O empreiteiro, de acordo com o artigo 625 e incisos do Código Civil, poderá suspender a obra: (i) por culpa do dono, ou por motivo de força maior; (ii) quando houver dificuldades imprevisíveis de execução dos serviços, resultantes de causas geológicas ou hídricas, ou outras semelhantes, de modo que torne a empreitada excessivamente onerosa, e o dono da obra se opuser ao reajuste do preço inerente ao projeto por ele elaborado, observados os preços; ou (iii) se as modificações exigidas pelo dono da obra, por seu vulto e natureza, forem desproporcionais ao projeto aprovado, ainda que o dono se disponha a arcar com o acréscimo de preço.

Ressalta-se, no entanto, a relevância prática da onerosidade excessiva e da teoria da imprevisibilidade, previstas no inciso II do artigo 625 do Código Civil. Imaginemos, por exemplo, que ao elaborar o projeto, considerou-se certo tipo de solo sobre o qual a obra seria construída, mas posteriormente, em virtude de contaminação ou da constatação de existência de sítios arqueológicos, deu-se a impossibilidade de prosseguimento da obra. Nessa hipótese, a construção do projeto originário 
geraria gastos acima daqueles inicialmente previstos, pois as condições reveladas a posteriori geraram um desequilíbrio nas prestações do contrato.

É evidente que se trata de uma medida que visa proteger o empreiteiro, na medida em que este poderá reclamar reequilíbrio financeiro e econômico do contrato diante de prejuízos decorrentes de situação excepcional e/ou imprevisível.

Por fim, como última característica, a extinção do contrato de empreitada ocorre pelo seu cumprimento, ou seja, pela entrega da obra objeto do contrato, podendo ainda ser considerado como resolvido o contrato caso uma das partes não cumpra com qualquer das cláusulas assumidas. 


\title{
CAPÍTULO III \\ A NATUREZA JURÍDICA DO CONTRATO DE EPC
}

\begin{abstract}
Sumário: 3.1. O Contrato de EPC à luz da normatização aplicável ao contrato de empreitada; 3.1.1. Quanto ao objeto e escopo; 3.1.2. Caso fortuito e força maior e os critérios objetivos de caracterização no instrumento contratual; 3.1.3. A garantia quinquenal e o repasse da garantia; 3.1.4. A "hipossuficiência" do contratante e as ordens de mudança; 3.1.5. O pagamento e as medidas parciais do projeto (milestones); 3.1.6. A aceitação dos trabalhos; 3.2. A empreitada é a tipificação adequada ao Contrato de EPC?; 3.3. A não tipificação do Contrato de EPC no ordenamento jurídico brasileiro
\end{abstract}

\subsection{O Contrato de EPC à luz da normatização aplicável ao Contrato de Empreitada}

Em um mundo globalizado, muitos Contratos de EPC são celebrados entre empresas de diferentes países, que, consequentemente, se submetem a diferentes jurisdições. Assim, a escolha da lei aplicável assumirá grande relevância caso haja disputa entre duas ou mais partes de um contrato no cenário internacional.

Sobre o tema assinala BONOMI:

"a lei escolhida pelas partes durante o processo de negociação do empreendimento será aplicada quando da interpretação dos termos e condições dos contratos e das penalidades e suas formas de aplicação, se for o caso." ${ }^{34}$

No Direito Internacional, tradicionalmente, a autonomia da vontade é o princípio que deve reger as obrigações, devendo as partes escolher a lei que regulará seu contrato. Este princípio, todavia, encontra barreiras em nosso ordenamento jurídico diante do princípio da territorialidade, que vem a estabelecer restrições materiais à liberdade de escolha das partes pela lei

\footnotetext{
${ }^{34}$ BONOMI, Cláudio A.; MALVESSI, Oscar. Op. cit., p. 80.
} 
de regência do contrato formalmente constituído em território nacional, conforme redação do artigo $9^{\circ}$ da LICC:

“Art. 9o Para qualificar e reger as obrigações aplicar-se-á a lei do país em que se constituírem.

"§ 1o Destinando-se a obrigação a ser executada no Brasil e dependendo de forma essencial, será esta observada, admitidas as peculiaridades da lei estrangeira quanto aos requisitos extrínsecos do ato.

$\S 20$ A obrigação resultante do contrato reputa-se constituída no lugar em que residir o proponente." 35

No entanto, o princípio da territorialidade possui conotação de norma supletiva, aplicando-se apenas quando o contrato for omisso acerca da lei aplicável, ao passo que prevalecerá sobre ele a autonomia da vontade das partes em contratar, sendo permitido a estas a escolha da lei mais adequada para reger seu contrato internacional.

Ao contrário do que afirmam alguns, isso não representa qualquer ofensa à ordem pública brasileira. Naturalmente, a escolha da lei aplicável possui limitações, mas a própria lei brasileira se encarrega disso ao afirmar que não prevalecerão as disposições da lei estrangeira que contrariarem a ordem pública brasileira, os bons costumes ou a soberania nacional. ${ }^{36}$

Os motivos que determinam tal escolha são igualmente legítimos. Geralmente são escolhidas as leis consideradas mais sofisticadas para o objeto do contrato, advindas do país onde o negócio em questão foi mais desenvolvido e, consequentemente, onde a lei pôde ser refinada e apreciada com maior profundidade ao longo dos anos. ${ }^{37}$

\footnotetext{
${ }^{35}$ BRASIL, Decreto-Lei n. 4.657, de 4 de setembro de 1942, Lei de Introdução ao Código Civil Brasileiro. Diário Oficial [da] República dos Estados Unidos do Brasil, Rio de Janeiro, 9 de setembro de 1942

${ }^{36}$ CINTRA, Antonio Felix de Araujo; BERGER, Renato. Lei aplicável: uma questão de escolha. Jus Navigandi, Teresina, ano 9, n. 250, 14 mar. 2004. Disponível em: $<$ http://jus.uol.com.br/revista/texto/4942/lei-aplicavel-uma-questao-de-escolha>. Acesso em: 26 mai. 2011.

${ }^{37}$ Ibid.
} 
Por outro lado, se o empreendimento for executado em território nacional, poderá ser vantajoso para a parte que tiver sede no país que o Contrato de EPC seja regulado pela lei brasileira pelos seguintes motivos: (i) maior facilidade de solucionar possíveis conflitos de interesses entre as partes; (ii) maior possibilidade de gerenciamento do projeto; e (iii) economia quanto aos custos relacionados à contratação de escritórios de advocacia especializados em outra lei que não a nacional.

Diante da escolha da lei brasileira para reger um Contrato de EPC, que, por sua vez, não possui regulamentação específica em nosso ordenamento jurídico, importante será a determinação de quais regras que lhes serão aplicáveis dentre os diversos institutos contratuais tipificados. Isso porque, como dito no item 2.2, referente à classificação dos contratos, dependendo da modalidade de contratação escolhida para atender a necessidade das partes, os efeitos jurídicos decorrentes de tal classificação poderão se manifestar das mais variadas formas no caso concreto.

Como solução, é possível a aplicação da teoria da interpretação analógica, cujo método consiste na tarefa do interprete de procurar o contrato típico do qual mais se aproxima o contrato atípico para, então, aplicar a esse as normas que disciplinam aquele. Se este recurso falha, por não haver contrato típico com o qual tenha o contrato atípico maior afinidade, prevalecerão os princípios gerais do Direito Contratual. ${ }^{38}$

Diante do exposto, partindo-se da análise de um Contrato de EPC em que a lei escolhida for a brasileira e, interpretando-o analogicamente com as regras da empreitada por destas mais se aproximarem em termos de tipificação, é possível destacar alguns impactos relevantes que surgirão a partir deste marco contratual, tanto para o empreiteiro quanto para o dono da obra, conforme se falará nos subitens adiante.

\footnotetext{
${ }^{38}$ GOMES, Orlando. Op. cit., p. 107.
} 


\subsubsection{Quanto ao objeto e escopo}

O objeto do contrato é o conjunto das obrigações principais nucleares que as partes se comprometem a executar. ${ }^{39} \mathrm{O}$ termo escopo, por sua vez, confunde-se com o objeto, mas pode ser tratado numa acepção mais estreita, significando todo o conjunto de materiais, serviços e equipamentos que compõe o objeto do contrato.

Nesse sentido, o artigo 610, parágrafo $1^{\circ}$ do Código Civil estabelece que a obrigação do empreiteiro de fornecer os materiais deve estar expressa no contrato, ou prevista em lei, sob pena de não poder ser exigido pelo dono da obra esse fornecimento. Logo, é de suma importância que as partes, quando da negociação de um Contrato de EPC para a construção de um grande empreendimento, estipulem o correto delineamento do escopo que será executado.

Similarmente, se as partes pretendem contratar o projeto da obra, bem como sua execução, como em regra ocorre nos Contratos de EPC Turnkey Lump Sum, é essencial que esse escopo seja redigido da forma mais objetiva no contrato. Se assim não for, o dono da obra não poderá exigir do projetista a sua execução. O mesmo se aplica no caso de as partes desejarem que o projetista da obra supervisione a sua execução.

Normalmente, nos Contratos de EPC, detalha-se no objeto que a contratada realizará o projeto (incluindo os desenhos de as built, que são os desenhos definitivos do empreendimento), as obras, serviços e fornecimentos, inclusive o comissionamento necessário à realização plena e integral do empreendimento. Pode-se ainda considerar que podem fazer

\footnotetext{
${ }^{39}$ GOMES, Orlando. Op. cit., p. 56.
} 
parte do escopo os serviços de campo e investigações relacionadas ao solo, da água, além de todos os ensaios e testes necessários.

Por outro lado, se o projeto for realizado pelo dono da obra ou por terceiro, as partes devem estabelecer se o empreiteiro deverá rever o projeto e identificar quaisquer irregularidades ou pontos que mereçam esclarecimentos, devendo renunciar ao direito de imputar qualquer falha no cumprimento do contrato a erros do projeto. Normalmente o empreiteiro possui um prazo para apontar os erros do projeto, passado esse prazo, quaisquer erros identificados no projeto deverão ser remediados à custa do empreiteiro.

Em suma, nos Contratos de EPC, a cláusula quanto ao objeto e escopo deverá ser extremamente detalhada, contemplando todas as atividades necessárias à consecução do empreendimento, para que não haja dúvidas quanto ao seu alcance, devendo-se ainda prever a restrição de que todo o escopo será executado conforme previsto nos documentos anexos ao contrato, ou seja, conforme projeto e especificações técnicas.

\subsubsection{Caso Fortuito e Força Maior e os critérios objetivos de caracterização no instrumento contratual}

A redação do artigo 618 do Código Civil atual baseia-se na redação do artigo 1.245 do Código Civil de 1916, conforme se verifica abaixo:

\footnotetext{
"Art. 618. Nos contratos de empreitada de edifícios ou outras construções consideráveis, o empreiteiro de materiais e execução responderá, durante o prazo irredutível de cinco anos, pela solidez e segurança do trabalho, assim em razão dos materiais, como do solo.
} 
Parágrafo único. Decairá do direito assegurado neste artigo o dono da obra que não propuser a ação contra o empreiteiro, nos cento e oitenta dias seguintes ao aparecimento do vício ou defeito." ${ }^{, 40}$

"Art. 1245: Nos contratos de empreitada de edifícios ou outras construções consideráveis, o empreiteiro de materiais e execução responderá, durante 5 (cinco) anos, pela solidez e segurança do trabalho, assim em razão de seus materiais, como do solo, exceto, quanto a este, se não o achando firme, preveniu em tempo o dono da obra."

Comparando-os, é possível notar que o atual artigo aumentou de forma significativa a responsabilidade do contratado, ao suprimir a ressalva legal quanto às condições do solo, que poderia eximir a responsabilidade do empreiteiro caso ele as denunciasse. Com o novo Código Civil, ficou estipulado que o empreiteiro não poderá ser eximido quanto à responsabilidade do solo, mesmo advertindo o dono da obra quanto a isso.

Entretanto, como alternativa à rigidez estipulada, poderá o Epecista (i) recusar-se a executar a obra, eximindo-se do pagamento da indenização pelos danos sofridos pelo dono da obra ou (ii) deverá provar a existência de caso fortuito ou força maior (force majore), prevista no artigo 393 do Código Civil.

O conceito de Caso Fortuito é associado a uma ocorrência humana, de caráter imprevisível, e por isso inevitável. Já o conceito de Força Maior, é associado a eventos de natureza, podendo até ser de caráter previsível, porém também inevitável. A caracterização de Caso Fortuito ou Força Maior reside na articulação de duas ideias: (i) fato inescapável e (ii)

\footnotetext{
${ }^{40}$ BRASIL. PRESIDÊNCIA DA REPÚBLICA. Código Civil. Lei n ${ }^{\circ} 10.406$, de 10 de janeiro de 2002. Disponível em: <http://www.planalto.gov.br/ccivil_03/LEIS/2002/L10406.htm>. Acesso em: 10 mar. 2011.

${ }^{41}$ BRASIL. PRESIDÊNCIA DA REPÚBLICA. Código Civil. Lei $\mathrm{n}^{\circ} 3071 \mathrm{de} 1^{\circ}$ de janeiro de 1916. Disponível em: < http://www.planalto.gov.br/ccivil/leis/L3071.htm >. Acesso em: 10 mar. 2011.
} 
impossibilidade de evitar/ impedir os efeitos desse fato, cujos efeitos não eram possíveis ser impedidos ou evitados. ${ }^{42}$

Diante disso, é de suma importância que nos Contratos de EPC haja uma cláusula mais objetiva possível quanto aos critérios básicos para a caracterização dos eventos de Caso Fortuito e Força Maior, evitando quaisquer interpretações subjetivas quanto a isso.

Quanto ao tema, sabiamente ensina NUNES PINTO:

"O procedimento correto a se adotar, no que tange às hipóteses elencadas pela legislação, será o de regular minuciosamente no contrato o tratamento aplicável, inclusive determinando o que constituirá ou não evento de força maior. Essa regulamentação deverá existir e estar mencionada como vinculada à referida disposição legal e como forma de implementá-la, afastando-se dessa forma uma aplicação do texto amplo e não discriminado da lei”. ${ }^{43}$

Nesse sentido, para que a responsabilidade do Epecista quanto ao solo do empreendimento seja delineada de uma maneira equilibrada, garantindo a aplicação do artigo 393 do Código Civil, sugere-se que determinados eventos de natureza que impliquem na qualidade do solo sejam incluídos na relação de eventos considerados como de Força Maior.

Caso o Epecista não seja capaz de provar tais eventos que configurariam uma excludente de antijuricidade, ele responderá pela indenização dos danos sofridos pelo dono da obra ocorridos em função da ausência de solidez, segurança e inadequação de seu trabalho, de acordo com o artigo 618 do Código Civil.

\footnotetext{
${ }^{42}$ CAVALCANTI, Flávio de Queiroz Bezerra. Caso fortuito e força maior frente a técnica securitária. Jus Navigandi, Teresina, ano 7, n. 56, 1 abr. 2002. Disponível em: <http://jus.uol.com.br/revista/texto/2829> Acesso em: 25 mai. 2011.

${ }^{43}$ PINTO, José Emílio Nunes. Op. cit., p. 90.
} 


\subsubsection{A garantia quinquenal e o repasse da garantia}

Além do artigo 618 do atual Código Civil ter agravado a responsabilidade do contratado no que tange às condições do solo, o mesmo artigo agravou mais ainda a responsabilidade do contratado ao tornar expressamente irredutível o prazo da garantia quinquenal. Diante desse fato, este artigo pode ser considerado como um dos mais impactantes quando da aplicação das regras do contrato de empreitada aos Contratos de EPC.

De acordo com este artigo, presume-se a responsabilidade do empreiteiro em questões de solidez e segurança da construção, durante "prazo irredutível de cinco anos" a contar de sua entrega. Após esse prazo, o ônus da prova transfere-se ao contratante.

Nas palavras de NUNES PINTO, destaca-se o fundamento desta garantia:

"O empreiteiro foi escolhido dentre diversos profissionais habilitados para construção da obra de grande porte e, por conseqüência, obrigou-se a entregá-la em perfeitas condições de operação e isenta de quaisquer vícios e defeitos. Assim sendo, caso existam vícios e defeitos aparentes ou ocultos, a legislação dá a eles tratamento diferenciado; em caso de vícios aparentes, poderá o contratante rejeitar o recebimento da obra, quanto aos ocultos, fixa prazo para que o empreiteiro os corrija. $\mathrm{O}$ impacto decorre sobretudo em relação aos custos associados à duração dessa garantia." ${ }^{44}$

A situação estaria solucionada caso estivéssemos falando somente das parcelas de construção civil, tais como o ferro, areia, concreto e tubos. Neste caso, não haveria qualquer complexidade quanto à aplicação deste artigo aos Contratos de EPC. Contudo, deve-se ter em mente que as obras de grande porte na área de infraestrutura envolvem o fornecimento de máquinas e equipamentos, como, por exemplo, turbinas, compressores e etc., o que, seria forçoso reconhecer se tratar de uma parcela de construção civil.

\footnotetext{
${ }^{44}$ Ibid. p. 80.
} 
Além disso, na prática dos Contratos de EPC, as garantias dessas máquinas e equipamentos são repassadas pelo fornecedor/fabricante diretamente ao contratante, sendo que tais garantias, de acordo com as práticas da indústria, não tem excedido o prazo médio de 24 meses.

Logo, parece desproporcional a imposição da garantia quinquenal ao Epecista, uma vez que elevaria em três anos a responsabilidade deste por uma obrigação que não está coberta pela garantia do fabricante, já que foi repassada ao dono da obra.

\subsubsection{A "hipossuficiência" do contratante e as ordens de mudança}

O artigo 620 do Código Civil, ao prever a possibilidade revisão do preço global inicialmente convencionado, aparenta proteger o contratante considerando-o hipossuficiente em relação ao empreiteiro, sem levar em consideração a nova realidade das contratações das grandes obras de engenharia que ocorrem em nosso país.

É notório que a hipossuficiência do contratante não é característica das obras de grande porte, visto que todos os que estejam envolvidos em operações desta natureza conhecem muito bem as longas e intermináveis negociações entre contratantes e empreiteiros para a determinação do valor global da empreitada chave na mão (Turnkey).

Ademais, em muitos destes contratos, a fixação do preço poderá ser baseado no procedimento open book, no qual o dono da obra tem acesso aos custos e margens incorridos pelo empreiteiro e os quais foram levados em consideração para fixação do valor global. ${ }^{45}$ Nesse caso, o dono da obra

\footnotetext{
${ }^{45}$ Ibid. p. 87.
} 
poderá acessar os livros contábeis relativos à obra a fim de saber precisamente o que está sendo gasto.

O pedido de revisão do preço estipulado no artigo 620 não aparenta ser adequado, na medida em que, nos Contratos de EPC, o contratado já corre o risco do aumento dos componentes que entraram na formação do preço global, sem direito a qualquer aumento. Salvo casos em que esse aumento se enquadre na teoria da imprevisão prevista no artigo 478 e seguintes do Código Civil, a título de onerosidade excessiva.

Diante do exposto, não há dúvidas de que este artigo do Código Civil apresenta uma redação frágil frente às grandes obras de infraestrutura, podendo, caso seja erroneamente reconhecida a hipossuficiência, acarretar em grandes instabilidades entre o Epecista e o contratante durante a negociação do contrato, visto que o último estará consideravelmente protegido por este artigo.

Além disso, cabe ainda falar que ajustes quanto à concepção de projeto no âmbito de um Contrato de EPC (tanto das estruturas quanto dos equipamentos) são extremamente normais, sobretudo por conta das adaptações às condições do local de implantação. Essas são as chamadas change orders que devem ser objeto de negociação e acordo pelas partes, de modo que alterações ao escopo original dependam de expressa aprovação do contratante.

Destaca-se que os ajustes serão objeto de acordo entre as partes, devendo ser estabelecido contratualmente um procedimento para disciplinar a forma de apresentação das propostas pelo contratado e da aprovação pelo contratante, de modo a preservar a continuidade dos serviços, mesmo em casos em que as partes ainda não tenham chegado a um acordo comercial. 
É importante ainda que nos Contratos de EPC seja imposta ao Epecista a obrigação de dar sequência ao empreendimento, mesmo que haja discordância quanto ao preço, sempre em prol da continuidade e conclusão tempestiva da obra, bem como da perspectiva de manutenção de seu fluxo de caixa.

\subsubsection{O pagamento e as medidas parciais do projeto (milestones)}

No âmbito da negociação das cláusulas sobre pagamento, as partes deverão acordar em que momento o pagamento será devido, levando-se em conta se a obra será realizada em partes distintas, através de cumprimento de etapas, ou se será realizada como um conjunto unitário, sendo certo que tal decisão dependerá diretamente da natureza do empreendimento que se pretende realizar.

A maior dificuldade está no primeiro caso, pois as partes devem atentar para o fato de que o Código Civil estabelece que as partes da obra que tiverem sido pagas serão presumidas como verificadas pelo dono da obra. E no caso de contratação por medidas parciais (ou chamadas de milestones nos contratos anglo-saxões) se as partes concordarem que haverá um pagamento por cada milestone cumprido, deverão considerar que, uma vez pago, o milestone será considerado como verificado pelo dono da obra, nos termos do artigo 614, parágrafo $1^{\circ}$ do CC.

Portanto, o Contrato de EPC deverá prever de que forma ocorrerão os pagamentos. Se for o caso do pagamento mediante o cumprimento de cada por cada milestone cumprido, para uma maior segurança e controle pelo Contratante, o Epecista deverá apresentar relatórios de medição contendo descrição do serviço prestado, os quais deverão ser aprovados pelo contratante para que então ocorra o pagamento. 
Já no segundo caso, em se tratando do pagamento unitário pelo conjunto da obra, pode-se estipular que o pagamento será feito somente após a execução de todo o serviço e desde que haja aceitação deste pelo contratante, conforme será falado no seguinte item.

\subsubsection{A aceitação dos trabalhos}

O encerramento de um Contrato de EPC é sempre objeto de muita discussão. É comum contratos levarem anos para serem encerrados mesmo após a entrada em operação do empreendimento. Dada a complexidade do objeto deste contrato, não é raro que muitas pendências persistam por muito tempo, muitas delas, inclusive objeto de controvérsia. Nestes casos, ocorre longa discussão entre o contratante e o contratado em torno do encerramento do contrato.

Cláusulas que disciplinam o encerramento do Contrato de EPC são exigidas pelo contratado como meio de proteção contra exigências exageradas e não respaldadas no instrumento contratual. Estas cláusulas regulam o mecanismo pelo qual o dono da obra aceitará os trabalhos executados. A relevância disto está relacionada, dentre outros fatores, à transmissão do título de propriedade após a medição e aceitação pelo dono da obra do empreendimento, fazendo iniciar a contagem dos períodos de garantia contratual e legal.

Para que haja o encerramento contratual, faz-se a emissão do chamado "certificado de aceitação final" que deverá ser vinculado ao cumprimento de todas as obrigações contratuais e a não existência de qualquer pendência. Poderá ocorrer ainda a aceitação provisória, o que possibilita o dono da obra a operar o empreendimento enquanto eventuais desconformidades são sanadas pelo Epecista. 
Vale destacar que no tocante a aceitação/ medição, as partes devem atentar para o artigo 614, parágrafo $2^{\circ}$ do Código Civil que prevê que, havendo medição, o dono da obra deve denunciar quaisquer irregularidades no prazo máximo de 30 (trinta) dias, sob pena do item vir a ser considerado como verificado pelo dono da obra.

Adicionalmente, sugere-se que seja estipulado que a emissão do certificado de aceitação final não isentará o contratado das responsabilidades remanescentes no âmbito do Contrato de EPC, tais como aquelas disciplinadas na cláusula de responsabilidade por perdas e danos, destacando-se a ocorrência de negligência, imperícia, imprudência, ilícitos e omissões causadas pelo contratado ao dono da obra ou a terceiros.

\subsection{A empreitada é a tipificação adequada ao Contrato de EPC?}

Em se tratando de Contratos de EPC, que não possuem previsão legal expressa no nosso ordenamento jurídico, o exercício de estabelecer a natureza jurídica deste tipo de contratação torna-se importante na medida em que, a partir dessa análise, pode ser verificada de que forma a legislação brasileira interpretará determinadas obrigações originalmente concebidas no direito anglo saxão e, consequentemente, de que forma essas regras podem ser "tropicalizadas" diante de um caso concreto.

Segundo JOSÉ EMÍLIO NUNES PINTO, dada a similaridade existente entre o Contrato de EPC e o contrato de empreitada, poder-se-ia argumentar que o Contrato de EPC é uma manifestação da empreitada e que tem a mesma natureza jurídica desta. ${ }^{46}$

\footnotetext{
${ }^{46}$ PINTO, José Emílio Nunes. Op. cit., p.74.
} 
Porém, esta não pode ser considerada uma verdade absoluta, pois os Contratos de EPC se distanciam do contrato de empreitada na medida em que constituem uma relação muito mais complexa em termos contratuais, principalmente quanto às diversas obrigações assumidas pelo Epecista, conforme explicitado no item 1.3 deste estudo, as quais vão além do cumprimento da empreitada pura e simples.

Assim, nota-se que a aplicação das regras da empreitada a este tipo de contratação causaria um marco contratual frágil e inadequado à realidade econômica das respectivas operações, conforme muito bem observa NUNES PINTO:

"A hipótese de enquadramento do contrato de EPC no marco da empreitada seria amesquinhar o escopo da relação jurídica existente entre o Epecista e o contratante. Equivaleria enquadrar o contrato num tipo legal com base na atividade mais preponderante no complexo de todas as atividades, criando-se assim uma distinção internamente ao contrato que não corresponde ao que existe na prática." ${ }^{47}$

Quanto à classificação do Contrato de EPC, diante das diferentes relações jurídicas desempenhadas pelo Epecista, NUNES PINTO conclui que se trata de um contrato atípico misto:

"O contrato de EPC pode ser classificado como um contrato atípico misto, já que engloba obrigações das partes que são encontradas em mais de um contrato típico. No entanto, a correlação entre essas obrigações e respectivas contraprestações faz com que se crie um arranjo contratual diverso dos dois ou mais de que essas obrigações se originam, representando uma verdadeira fusão das disposições de ambos num todo unitário.",

"O contrato EPC é um contrato atípico, a despeito de conterem disposições de contratos típicos, como o de empreitada e de venda e compra de equipamentos. Na prática, as disposições legais aplicáveis a esses contratos típicos se tornam imprestáveis para regular as relações decorrentes dos EPCs. Assim sendo, necessário será que, como já o são, os EPCs continuem a regular detalhadamente as relações entre epecista e contratante, lembrando-se, no

\footnotetext{
${ }^{47}$ PINTO, José Emílio Nunes. Op. cit., p. 93.

${ }^{48}$ Ibid. p. 96.
} 
entanto, que as disposições desses contratos não poderão violar a ordem pública, os bons costumes e os princípios gerais de direito." ${ }^{49}$

Embora as regras da empreitada nem sempre sejam adaptáveis à realidade do que ocorre nos Contrato de EPC, é importante ter em mente que, conforme falado no item 3.1, em se tratando de um Contrato de EPC regido pela lei brasileira, as partes terão necessariamente que observar a aplicação dos artigos 610 a 626 do Código Civil. Primeiro pelo fato de que, por analogia, o Contrato de EPC possui grande relação com a empreitada, e segundo porque se trata de uma norma de ordem pública que possui caráter cogente.

Além disso, como explicitado nos subitens do item 3.1, é possível afirmar que, pelo menos, o contrato de empreitada será utilizado como referência para a elaboração do "arranjo contratual" dos Contratos de EPC, podendo, em alguns casos, serem afastadas pelas partes aquelas regras do Código Civil que não se adequarem a esse tipo de contratação como, por exemplo, aquelas que impactarem: (i) nos efeitos dos pagamentos (artigo 614), (ii) no direito de suspensão do contrato pelo Epecista (artigo 625); (iii) nas garantias (artigo 618); bem como sobre a (iv) possibilidade de revisão do preço do contrato (artigo 620).

Nesses casos, havendo controvérsias, caberá ao árbitro (caso haja previsão de arbitragem) ou ao poder judiciário decidir quanto à possibilidade de se afastar tais regras no caso concreto.

Conclui-se que, no que tange à natureza jurídica do Contrato de EPC, o melhor entendimento é que este é um contrato atípico misto dependente de uma detalhada regulamentação entre o contratante e Epecista. Porém, partindo-se de uma interpretação analógica dos dispositivos de um Contrato de EPC, estes sem dúvidas mais se aproximarão das regras da empreitada,

\footnotetext{
${ }^{49}$ Ibid. p. 97.
} 
não podendo as partes ignorar este fato durante a elaboração de suas cláusulas contratuais.

Assim, na prática, é fundamental o envolvimento de advogados experientes com este tipo de negociação, uma vez que estes não só atuam como consultores legais, indicando quais regras da empreitada deverão ser observadas, mas também acabam auxiliando seus clientes em questões não puramente jurídicas e que são essenciais à boa negociação, como aquelas relacionadas a implementação e operacionalização do empreendimento. ${ }^{50}$

\subsection{A não tipificação do Contrato de EPC no ordenamento jurídico brasileiro}

Feita a análise da natureza jurídica do Contrato de EPC e chegandose a conclusão de que este pode ser entendido como um contrato atípico misto em que as partes não devem ignorar as regras relativas ao contrato de empreitada, inevitavelmente surge a seguinte pergunta quanto aos Contratos de EPC: Por que o Código Civil de 2002 não previu uma tipificação específica para este tipo de contrato, dada a sua larga utilização no Brasil desde o final da década de 90 ?

Primeiramente, conforme analisado no item 2.2, os contratos atípicos visam atender ao dinamismo das relações sociais e respectivas naturezas econômicas. Caso fossem tipificados no ordenamento jurídico todas relações passíveis de contratação, certamente não haveria uma atualização fiel das leis acompanhando as novas relações jurídicas que surgissem. Assim ocorre nos Contratos de EPC, que estão em constante adequação às diferentes práticas do mercado.

\footnotetext{
${ }^{50}$ BONOMI, Cláudio A.; MALVESSI, Oscar. Op. cit., p. 82.
} 
Além disso, o Brasil ainda possui pouca experiência e familiarização com esse tipo de contratação. De fato, os primeiros Contratos de EPC começaram a surgir no Brasil no final do século passado, podendo-se citar como exemplo o caso da Usina Hidrelétrica de Itá, em 1996, que foi a primeira concessão de energia elétrica compartilhada com o setor privado. Logo, este pode ser apontado como o segundo fator determinante para se cogitar a razão pela qual não há legislação codificada para os Contratos de EPC.

Por fim, o terceiro e último aspecto que pode ser levantado quanto à falta de necessidade de tipificação dos Contratos de EPC é que, em muitos casos, estes são celebrados entre empresas de diferentes países, no âmbito do project finance, em que, muitas vezes, é prevista a aplicação de lei estrangeira para interpretação das regras aplicáveis, bem como a arbitragem como método de solução de conflitos.

Desta maneira, os escritórios de advocacia, bem como as partes que participam do empreendimento acabam se baseando em modelos padrões elaborados por entidades internacionalmente reconhecidas, os quais vêm sendo utilizados por décadas no mundo todo, conforme se falará no próximo capítulo. O que não demanda, portanto, a urgência de previsão legal do Contrato de EPC.

Em suma, é possível afirmar que a adoção desta modalidade de contratação no Brasil se justifica pela simples inexistência de um modelo específico de contrato eficiente, capaz de assegurar a celebração de um instrumento completo e adaptado à realidade do país, que vem crescendo cada vez mais em termos de infraestrutura. 


\section{CAPÍTULO IV \\ O CONTRATO DE EPC EM OUTROS PAÍSES}

Sumário: 4.1. A importância da padronização dos contratos; 4.2. O padrão da FIDIC para Contratos de EPC Turnkey Projects; 4.3. Principais cláusulas que devem conter no Contrato de EPC; 4.3.1. Cláusula quanto ao prazo; 4.3.2. Cláusula quanto ao preço e forma de pagamento; 4.3.3. Cláusula de seguros; 4.3.4. Caso fortuito e força maior; 4.3.5. Danos acordados; 4.3.6 Cláusula de bônus; 4.3.7 Cláusula de legislação aplicável, solução de controvérsias e foro.

\subsection{A importância da padronização dos contratos}

Diante do project finance, em que se busca preservar o fluxo de caixa do empreendimento, a conclusão da obra dentro do prazo pode ser muito mais relevante do que o próprio custo da construção, pois os efeitos do atraso como a perda de receita da operação ou comercialização do que se pretende, bem como o pagamento das penalidades previstas contratualmente, acabam por representar prejuízo maior para as partes.

Nesse contexto, o Contrato de EPC, com seu escopo bem definido, mostra-se como uma boa solução para determinar contratualmente o preço final do empreendimento e sua data de conclusão. Além de baseados na premissa do project finance, os Contratos de EPC também se baseiam em métodos de construção testados e aprovados ao longo do tempo, que, conseqüentemente, acabam servindo como um precedente para as futuras contratações que visam a alocação de riscos entre as partes.

Diante destes precedentes, bem como da crescente celebração de contratos entre empresas de nacionalidades diferentes, fica nítido que um dos motivos principais para proposição de um modelo de Contrato de EPC é estabelecer uma padronização de contratos normalmente utilizados no 
mundo globalizado. Busca-se tal padronização através de cláusulas preestabelecidas que podem variar dependendo da legislação do país que será aplicável, bem como dependendo da natureza do empreendimento.

Existem organizações internacionais responsáveis por criar métodos de negócios e desenvolvimento de estudos para a área de construção, tais como: JCT (Joint Contract Tribunal), ICE (Institute of Civil Engineers), no Reino Unido, AIA (American Institute of Arquitects) nos Estados Unidos, BKK (Byggandets Kontrackts Kommité) na Suécia e a FIDIC (Federation Internacionale Des Ingenieurs-Conseils). ${ }^{51}$

Essas organizações elaboram modelos de contrato que, sem dúvida, promovem uma maior segurança entre as partes na medida em que estas podem se familiarizar de antemão com seu conteúdo. Além disso, partindo do princípio que as partes já conhecem os pontos fortes e fracos de um contrato padrão, podendo, portanto, fazer uma maior análise quanto às clausulas que lhes são favoráveis ou não, certamente haverá uma diminuição de custos no que se refere às horas despendidas com negociações.

Em suma, o objetivo da adoção de formas-padrão de um contrato é facilitar os acordos entre as diferentes partes, incluindo advogados e engenheiros que, por sua vez, possuem diferentes expectativas no empreendimento. $\mathrm{O}$ conhecimento, treinamento $\mathrm{e}$ aprendizado destes contratos padrão é importante, pois estes, embora sejam passíveis de negociação entre as partes, são a primeira escolha da maioria dos organismos internacionais financiadores de tais projetos.

\footnotetext{
${ }^{51}$ GÓMEZ, Luis Alberto. Op. cit., p. 28.
} 


\subsection{O padrão da FIDIC para Contratos de EPC Turnkey Projects}

Dentre os modelos de contrato elaborados pelas mencionadas organizações especializadas em projetos de infraestrutura, um que possui grande aceitação no cenário internacional é o da FIDIC, que, devido ao seu considerável reconhecimento, merecerá uma breve dissertação sobre sua atuação.

Trata-se de uma federação de profissionais de engenharia que nos últimos 40 anos vêm desenvolvendo inúmeros guias e modelos de contratos elaborados através de métodos e estudos, que são largamente adotados na Europa e demais partes do mundo quando tratam de serviços de grandes obras de engenharia. ${ }^{52}$

Os principais usuários dos contratos padrão da FIDIC são os fornecedores e empresas de engenharia que atuam em projetos multinacionais. A FIDIC possui tamanha relevância e respeito no cenário internacional que muitos financiadores dos empreendimentos estruturados a partir do project finance, como, por exemplo, o Banco Mundial, sugerem a adoção deste modelo para melhor alocação de riscos, o que é requisito essencial para outorga de financiamentos. ${ }^{53}$

A FIDIC redigiu os seguintes livros para as seguintes formas de gerenciamento de contratos, respeitadas as restrições e necessidades de ajustes às diversas situações em que se pretende contratar:

“- Green Book: é utilizado em contratos de pouca monta, pequenas obras;

- Red Book: é utilizado em contratos baseados em Lista de Materiais, em que há uma separação entre construção e projeto. Este tipo de contrato foi usado no século XIX e primeira metade do século XX. Atualmente está perdendo

\footnotetext{
${ }^{52}$ HUSE, Joseph A.Understanding and negotiating turnkey and EPC contracts. Thomsom Sweet and Maxwel, 2002, p. 29.

${ }^{53}$ GÓMEZ, Luis Alberto. Op. cit., p. 28.
} 
popularidade para contratos do tipo Preço Global (Lump Sum) onde a maior parte do risco é alocada para o fornecedor;

- Yellow Book: é utilizado em contratos do tipo Preço Global (Lump Sum) ou DB (Design and Build). O fornecedor recebe a incumbência de projetar e construir baseada numa lista de requerimentos do contratante;

- Silver Book: É usado quando uma empresa privada financia um projeto do tipo EPC. O fornecedor é responsável pela engenharia, compra e construção, e o cliente não se preocupa com os problemas do dia-a-dia., 54

Frente às novas contratações que vinham ocorrendo no final da década de 90, a FIDIC redigiu e publicou o livro "Conditions of Contract for EPC/ Turnkey Projects", que veio a criar um modelo de Contrato de $\mathrm{EPC}$, propondo um compartilhamento de riscos mais oneroso para o contratado.

Isso porque o empreendedor, diante das elaboradas formas de financiamento dos projetos, passou a preferir pagar preços mais altos tendo em contrapartida o valor global e o prazo pré-definido para finalização. Como consequência, os riscos suportados e contingenciados pelo contratado acabam refletindo no preço do contrato, que, por sua vez, acaba sendo mais caro se comparado à mesma obra contratada por meio de uma modalidade mais tradicional de contratação, como a empreitada pura e simples.

\section{O livro "Conditions of Contract for EPC/ Turnkey Projects" contém} explicações quanto à proposição de seu modelo, bem como as restrições quanto à sua aplicabilidade. É ressaltado que ajustes ao modelo proposto serão inevitáveis, sobretudo para a adaptação de determinadas cláusulas quanto (i) à legislação do país que se pretende realizar o empreendimento objeto do contrato; (ii) à observação de exigências usuais de agentes financiadores; (iii) quanto à concessão de garantias; dentre outras.

\footnotetext{
${ }^{54}$ Ibid.
} 
Abaixo, transcreve-se a estrutura do Contrato de EPC proposto pela FIDIC composto por vinte cláusulas, divididas em subcláusulas, as quais possuem todas as condições da contratação detalhadas em diversas páginas de seu livro "Conditions of Contract for EPC/ Turnkey Projects”.

1. Disposições gerais

2. O contratante (dono da obra)

3. A administração do dono da obra

4. A contratada

5. O projeto

6. Pessoal e mão de obra

7. Instalações, materiais e execução

8. Início, atraso e suspensão

9. Testes de finalização

10. Aceitação pelo cliente

11. Responsabilidade por defeitos

12. Testes finais

13. Mudanças e ajustes

14. Preço contratual e pagamentos

15. Rescisão do Contrato pelo dono da obra

16. Suspensão, rescisão do contrato pelo Contratado

17. Riscos e responsabilidades

18. Seguros

19. Forca maior

20. Reinvindicações, disputas e arbitragem ${ }^{55}$

Não há dúvidas de que o modelo proposto pela FIDIC funciona como uma ótima referência para as partes envolvidas na negociação das cláusulas do instrumento contratual que dá suporte ao empreendimento. Entretanto, não caberá a utilização deste modelo para toda e qualquer

\footnotetext{
${ }^{55}$ Disponível em: http://www1.fidic.org/resources/contracts/describe/FC-QB-A-AA-10.asp.
} 
situação, visto que cada obra possui suas especificidades e, portanto, demandam cláusulas contratuais que deverão ser adaptadas a cada caso concreto.

Nas palavras de NUNES PINTO:

"Na prática, o contrato de EPC é, por si só, um arranjo contratual que traz em seu bojo todo o conjunto de regras destinadas a regular as relações entre as partes. Cada situação deve ser minuciosamente regulada, assim como qualquer evento que, de qualquer forma, possa alterar a natureza de contrato., ${ }^{, 56}$

Nesse sentido, embora os contratos padrões sejam muito bem aceitos e utilizados pelas partes justamente pelo fato de serem elaborados a partir de experiências concretas, destaca-se que é praticamente impossível cobrir todas as eventualidades que possam ocorrer durante a evolução do projeto. Daí a importância da individualização das disposições do instrumento contratual para cada contratação específica. ${ }^{57}$

Assim é que, por exemplo, obras de engenharia destinadas à construção de um reator para a contenção de pastilhas de urânio enriquecido na indústria de geração por fonte nuclear terão especificidades não previstas em um contrato padrão.

Diante do exposto, dentre as diferentes obras de grande porte que podem ser implementadas por meio de Contratos de EPC, as características particulares de cada empreendimento exigirão soluções contratuais diversas, visto que a aplicação de um único modelo padrão para qualquer tipo de obra nesta modalidade não caracterizará solução eficiente.

\footnotetext{
${ }^{56}$ PINTO, José Emílio Nunes. Op. cit., p. 94.

${ }^{57}$ GÓMEZ, Luis Alberto. Op. cit., p. 27.
} 


\subsection{Principais cláusulas que devem conter no Contrato de EPC}

Em decorrência da complexidade e particularidades dos Contratos de EPC, não é raro que surjam controvérsias durante a execução do contrato. Nesse contexto, poderão surgir consequências negativas relevantes advindas da redação de suas cláusulas, tais como: comprometimento da intenção das partes, problemas de interpretação de cláusulas, dificuldades de administração contratual em decorrência da imprecisão das cláusulas e etc.

Associados à complexidade da redação, outros aspectos também comprometem a qualidade dos Contratos de EPC, a saber: falta de ordenação lógica das cláusulas, previsão de penalidades em diversas cláusulas que não na própria cláusula de penalidades, excesso de remissões; multiplicidade de anexos muitas vezes desnecessários; falta de clareza nas cláusulas de conteúdo estritamente técnico, dentre outras.

Portanto, não é raro a celebração de contratos ineficientes, com ausência de cláusulas relevantes que poderiam resolver importantes controvérsias. Se tais situações fossem devidamente reguladas no Contrato de EPC, e caso surgisse algum problema durante sua execução ou desavença entre as partes, estes seriam resolvidos de acordo com o que estipula o contrato, não dependendo da intervenção do Estado, e nem mesmo de um árbitro.

Logo, o Contrato de EPC deverá conter algumas cláusulas que são essenciais para estruturar essa modalidade de contratação, constando em seu texto, de maneira detalhada e minuciosa, todas as situações que podem vir a se concretizar, atendendo da maneira mais harmoniosa possível os interesses de extrema oposição entre o contratante e o contratado. 
Embora já tenha sido feito a análise de algumas cláusulas do Contrato de EPC sob a ótica das regras da empreitada, será feita adiante uma análise das cláusulas que devem ser observadas para a boa negociação dos pontos mais importantes de um Contrato de EPC. Trata-se de cláusulas comumente adotadas por diversos países que, devido a sua vasta utilização e experiência com esse tipo de contratação, possuem regras refinadas e adaptadas às práticas do mercado.

\subsubsection{Cláusula quanto ao prazo}

Um Contrato de EPC deve ter um escopo bem definido, assim como o prazo, devendo o empreendimento ser entregue na da estipulada e com a qualidade requerida. Assim, nesta cláusula devem ficar definidos os prazos para entrada em operação comercial do empreendimento bem como os cronogramas que deverão ser produzidos pelo contratado para viabilizar o acompanhamento do cumprimento das etapas intermediárias da implantação.

É de suma importância que sejam estabelecidas condições específicas em que o prazo pode ser alterado, de modo a garantir, ao máximo, a preservação do prazo contratual, que é um dos pilares do Contrato de EPC e da premissa do projcet finance.

Contudo, vale ressaltar que as principais condições que normalmente permitem a prorrogação do prazo contratual são o inadimplemento por parte do contratante (e.g., a descontinuidade de licenças ambientais relacionadas ao projeto sob responsabilidade do contratante) e a ocorrência de eventos de Caso Fortuito ou Força Maior, nos termos da cláusula específica quanto a isso. 


\subsubsection{Cláusula quanto ao preço e forma de pagamento}

Nesta cláusula deverá ser definido expressamente o preço global do Contrato de EPC, levando-se em conta os principais itens, quais sejam: projeto, obras civis, fornecimento eletromecânico e montagem dos equipamentos.

Em regra, trata-se de uma soma global fixa, reajustável somente nas condições especificamente definidas no contrato. Além disso, é importante explicitar no contrato que o preço global considera o conhecimento prévio das condições do local de implantação, sendo certo que nenhum pleito de aumento de preço poderá ser solicitado pelo contratado baseado no desconhecimento das condições locais, falta, erro ou omissão de sua parte.

Devem ser definidos também os casos excepcionais nos quais poderão ocorrer a variação do preço, sendo que os principais são (i) os eventos de Caso Fortuito ou Força Maior, que serão regulados em cláusula específica, (ii) as alterações por ordem de variação (change orders) e (iii) mudanças na legislação.

Com relação ao segundo item, o Contrato de EPC também deverá prever uma cláusula específica prevendo aumento do preço inicialmente estipulado mediante as denominadas ordens de mudança ou change orders. Para isso deve-se prever o prazo razoável em que o Epecista deve ser notificado para que este tome as devidas providências quanto à mudança de escopo nos serviços. Tudo isso para evitar o surgimento de dúvidas ou dificuldades quanto à aferição do consentimento das partes.

Caso o preço seja pago mediante o cumprimento de etapas, como normalmente é estipulado, deve ser prevista ainda a forma que ocorrerá o pagamento deste. Assim, a periodicidade dos pagamentos poderá será 
mensal, mediante a apresentação de relatórios de medição apresentados pelo Epecista.

Os relatórios de medição são feitos com base na verificação do cumprimento de eventos de aferição, conforme documentação anexa ao Contrato de EPC. Esta documentação, por sua vez, prevê os eventos que serão o conjunto de atividades da obra definido de forma objetiva e que servem como critério de avaliação dos avanços. Tais eventos são elaborados em conformidade com os cronogramas físico e financeiro, que também serão parte integrante como anexo ao Contrato de EPC.

Ademais, deve-se estabelecer o mecanismo pelo qual serão realizadas as medições, incluindo o modelo do relatório de medição que será apresentado pelo Epecista e como ocorrerá a verificação em campo pelo contratante para aprovação da medição apresentada. Após a aprovação, ocorrerá o envio das faturas e, por fim, o pagamento.

É possível estipular condições específicas para o relatório de medição e faturamento, como, por exemplo, a apresentação de documentação comprobatória de recolhimento de tributos e encargos trabalhistas. Como regra, deve ficar estabelecido que o valor das medições mensais não poderá ultrapassar o valor máximo previsto no cronograma financeiro pois isso é uma medida que visa assegurar a previsibilidade do fluxo do investimento do projeto, fator necessário à utilização do modelo de project finance para financiamento.

\subsubsection{Cláusula de seguros}

Os seguros são instrumentos de garantias complementares cujo objeto é a cobertura de determinados eventos, muitas vezes alheio ao 
controle do contratado, e que podem impactar de maneira significativa no preço e o prazo da obra.

Logo, é extremamente importante a previsão desta cláusula obrigando a apresentação, pelo contratado, das apólices de seguro para cobertura de uma série de riscos associados ao empreendimento. Normalmente são estipulados os seguros de engenharia, seguro de transporte de materiais e equipamentos, seguro de responsabilidade civil e seguro de vida para os funcionários do consórcio construtor.

Para evitar questionamentos, deve-se prever que os custos com as apólices serão de responsabilidade do contratado e, para manter a aderência ao modelo do project finance, deve-se estabelecer que as apólices devem ser contratadas junto a seguradoras tradicionais ou de primeira linha, reconhecidas pelas práticas mercado. É claro que tais estipulações importarão em custos para o projeto.

Ademais, deve-se ainda ser ratificada nesta cláusula que a contração dos seguros não exime o contratado de suas obrigações no âmbito do Contrato de EPC, permanecendo este responsável por danos não cobertos pelo seguro ou cujo valor ultrapasse as eventuais indenizações pagas.

\subsubsection{Cláusula de Caso Fortuito e Força Maior}

Caso Fortuito e Força Maior são conceitos definidos no Código Civil brasileiro e se referem às situações em que o contratado não é responsabilizado pelos prejuízos causados. A concretização dos eventos de Caso Fortuito e Força Maior, em regra, é objeto de controvérsia entre as partes, por isso, sugere-se que, no Contrato de EPC, em complemento ao estipulado no artigo 393 do Código Civil, sejam listados de maneira 
objetiva os eventos que poderão ser considerados como Caso Fortuito ou Força Maior

Assim, essa relação de eventos deve conter ocorrências relacionadas não somente à ação humana que esteja além do controle, como greves e turbação, mas também eventos da natureza, tais como: período de chuvas, furacões e tudo mais que for possível ocorrer no contexto do Contrato de EPC e que não sejam resultado da ação ou omissão das partes.

É possível também excluir os eventos de caracterização de Força Maior, como, por exemplo, greves que apenas atinjam os funcionários da contratada, mas não toda a classe de trabalhadores.

Por fim, deve ser estabelecido quem será responsável por suportar os efeitos comprovadamente resultantes dos eventos previamente definidos como Caso Fortuito ou Força Maior. Como boa medida de assegurar o bom cumprimento do contrato, é bom prever expressamente que as partes se comprometerão a emprenhar os maiores esforços no sentido de minimizar os impactos deste eventos, sobretudo sobre o preço global e o cronograma de implantação.

\subsubsection{Cláusula de danos acordados}

No Contrato de EPC, como já estudado, o contratado se obriga a entregar o empreendimento no prazo e com a qualidade requerida, sob pena de pagar multas ou compensações previamente liquidadas. Esta cláusula visa estabelecer os critérios objetivos e valores destas compensações. Destaca-se que tais danos acordados ora se comportarão como cláusula penal moratória, prevista no artigo 409 do Código Civil, ora como cláusula penal compensatória, prevista no artigo 410 do Código Civil. 
Um ponto que deverá ser bem esclarecido nesta cláusula é quanto ao repasse do contratante ao contratado de penalidades impostas por autoridades governamentais, caso este tenha incorrido para isso. O contratado, por sua vez, deverá definir os danos acordados de forma objetiva e direta, procurando definir as penalidades que o contratante venha a receber de um agente externo e que poderá ser repassadas a ele.

Normalmente, os danos acordados, ou os chamados liquidated damages são estabelecidos para cobrir marcos intermediários de um projeto, como, por exemplo, o atraso de entrega de uma máquina ou da conclusão de determinadas obras civis. Podem ser atribuídos também a uma compensação por cada unidade de performance que deixou de ser agregada ao projeto e que, por via de consequência, implicará na queda do faturamento disponível para o projeto e seus financiadores.

Nesta cláusula devem ser definidas também penalidades por atraso, cujo valor é definido por multa diária ou em percentual do preço global, tendo sempre em mente a perda de receita auferida pelo contratante. Em regra, as perdas decorrentes de atraso são suportadas principalmente pelo contratado, devendo respeitar o limite de indenização estipulado no Contrato de EPC. O não pagamento pelo contratado das penalidades efetivamente devidas permite a execução de garantias contratuais por parte do contratante.

Por fim, caberá também a previsão de penalidade de rescisão por culpa do contratado. Neste caso, prevê-se normalmente verbas rescisórias equivalentes ao custo adicional incorrido pelo contratante para concluir a obra mediante a contratação de um terceiro, ficando a penalidade também restrita ao limite de indenização previsto no Contrato de EPC. ${ }^{58}$

\footnotetext{
${ }^{58}$ ENEI, José Virgílio Lopes. Op. cit., p. 62.
} 


\subsubsection{Cláusula de bônus}

Como um incentivo ao contratado para a conclusão da obra dentro do prazo e do orçamento, podem ser estabelecidas bonificações por antecipação e, em alguns casos, pelo desempenho superior ao estipulado no contrato do empreendimento. Neste último caso, cita-se como exemplo a produção de energia de uma hidrelétrica que vem a ser muito superior do que a capacidade prevista inicialmente.

Com relação à antecipação, pode-se estabelecer um bônus equivalente a um percentual da receita apurada com a comercialização do empreendimento realizado antes do período estipulado no contrato. Nesse caso, é comum que haja um rateio desse benefício em partes iguais, ou seja, $50 \%$ para contratante e $50 \%$ para a contratada. De modo que o contratante possa tomar as providências necessárias para tornar concreta a bonificação, é fundamental que o contratado notifique com razoável antecedência o contratante sobre a possibilidade de antecipação.

\subsubsection{Cláusula de legislação aplicável, solução de controvérsias e foro}

Tendo em vista a complexidade dos Contratos de EPC e a necessidade de prever expressamente todas as situações que podem vir a ser concretizadas, não é incomum a ocorrência de desentendimentos entre as partes no Contrato de EPC. Assim, para solução das controvérsias, como alternativa ao processo judicial, as partes podem prever outros mecanismos como a negociação assistida por meio de um conciliador ou a arbitragem.

Até então, percebe-se que a arbitragem vem sendo o mecanismo mais utilizado entre as partes do Contrato de EPC, podendo ser apontados 
os seguintes fatores como determinantes para sua adoção: (i) necessidade de celeridade para resolução das disputas que por ventura ocorram; (ii) segurança entre as partes quanto a pessoa que estará encarregada de solucionar o conflito, uma vez que supõe-se que esta terá expertise no assunto; e (iii) celebração de contratos em escala internacional, entre partes de diferentes países, envolvendo, portanto, diferentes jurisdições.

Com relação às despesas da arbitragem, considerando que determinados conflitos, muitas vezes, resumem-se a definição de valores, parece razoável que as despesas com o processo arbitral sejam suportadas igualmente por ambas as partes, e não o pagamento da despesa integral pela parte contra a qual a decisão arbitral for tomada.

No cenário internacional as câmaras arbitrais mais reconhecidas são a International Chamber of Commerce (ICC) e a American Arbitration Association (AAA) e a London Court of International Arbitration (LCIA). No Brasil, a arbitragem foi regulada pela Lei 9.307/2006. Não obstante o fato de possuirmos algumas câmaras arbitrais reconhecidas, como a Câmara de Comércio Brasil Canadá (CCBC), devido à recente utilização dos Contratos de EPC em nosso país, nenhuma delas possui larga experiência em averiguar conflitos decorrentes de Contratos de EPC como as câmaras internacionais possuem. 


\section{CONCLUSÃO}

O Brasil, assim como todos os demais países em desenvolvimento, depende sobremaneira de instrumentos econômicos financeiros e jurídicos que facilitem e viabilizem investimentos em infraestrutura. Nesse contexto, o project finance vem sendo cada vez mais adotado pelas empresas para captação dos investimentos necessários à concretização de seus empreendimentos, que, em regra, envolvem valores consideráveis.

A razão que faz como que os empreendedores, construtores e investidores financeiros de todas as partes do mundo utilizem o mecanismo do project finance para financiamento de tais projetos é uma só: cada um pode escolher o risco e o retorno que lhe parece mais adequado.

O Contrato de EPC, com seu escopo bem definido, permite que seja contratualmente previsto os custos e o prazo para a finalização do empreendimento, exigência fundamental dos financiadores. Conhecer as peculiaridades deste tipo de contrato é fundamental na medida em que é notável o aumento do número de proprietários de obras, construtores e operadores em busca desse modelo que vem sendo cada vez mais utilizado pelas práticas do mercado, tanto nacional quanto internacional, marcado pelas mais diversas jurisdições.

Através deste estudo, pretendeu-se identificar as características peculiares desta modalidade complexa de contratação. Para isso, o estudo foi realizado através de bibliografias sobre o gerenciamento dos Contratos de EPC, a sua estruturação financeira através do project finance, bem como doutrinas jurídicas relacionadas às características dos contratos em geral e do contrato de empreitada tipificado em nosso ordenamento jurídico. 
Por ser o contrato típico que mais se aproxima do objeto de um Contrato de EPC, foi feita uma análise da aplicação das regras do contrato de empreitada ao que normalmente se estipula nos Contratos de EPC, na qual foi possível identificar que esse marco contratual não é o mais adequado. Por isso, os contratos de EPC devem ser entendidos como contratos atípicos mistos, dependentes de uma detalhada regulamentação entre os contratantes, tendo sempre em vista as regras referentes ao contrato de empreitada.

Tratou-se também da importância da padronização dos Contratos de EPC, especificamente pelo modelo elaborado pela FIDIC, que é cada vez mais reconhecido pelos contratantes internacionais. Embora a necessidade de adaptar os modelos às circunstancias e legislação local de cada país, a disponibilidade de um contrato familiar e respeitado pela ordem jurídica é, sem dúvidas, um bom ponto de partida para as negociações das grandes obras de infraestrutura, economizando tempo e custos, principalmente nos casos em que pode haver significativas diferenças culturais entre as partes contratantes.

A primeira conclusão quanto ao estudo realizado é que, por se tratar de uma modalidade de contratação ainda recente, a bibliografia disponível sobre Contratos de EPC é muito escassa. Além disso, na prática, é possível constatar que existe falta de conhecimento e de consenso, até mesmo entre os especialistas, sobre as mais diversas matérias que envolvem um Contrato de EPC. Exemplo disso são imperfeições encontradas nos instrumentos contratuais, tais como excesso de remissões, diapositivos conflitantes entre cláusulas diferentes de um mesmo contrato e previsão de um grande número de anexos desnecessários.

De forma geral, conclui-se que um Contrato de EPC ideal é aquele prevê da maneira mais objetiva possível todas as situações que podem vir a 
se concretizar durante a execução do Contrato de EPC, evitando quaisquer interpretações subjetivas pelas partes. Ou seja, é aquele que prevê a extensão e complexidade do objeto contratual; o grau de precisão do projeto e dos estudos preliminares; o regime adequado para as medições reembolsos e pagamentos; bem como a possibilidade do empreendedor pretender e efetivamente poder exercer uma fiscalização eficiente da execução do empreendimento.

Definidos estes pontos, o Contrato de EPC ideal também deverá prever outros aspectos, tais como: os reais limites do preço global do contrato, das suas suspensões, paralizações, eventos de Caso Fortuito e Força Maior; quem deve arcar com os custos adicionais do empreendimento; quem vai arcar com as extensões de prazo do empreendimento; e quem se responsabiliza por eventuais defeitos ou inadequações do projeto.

Desnecessário enfatizar mais uma vez a grande responsabilidade dos advogados ao elaborar as cláusulas de um Contrato de EPC simulando as situações teóricas que darão origem às soluções contratualmente previstas. A melhor abordagem para esse processo é tomar as decisões sobre os objetivos comerciais do empreendimento, identificando os riscos a serem alocados de forma condizente com esses objetivos comerciais, e depois produzir um conjunto apropriado de documentos legais concebidos para atingir aquele fim específico. Jamais o inverso.

Esse procedimento combina a necessidade de uma convergência entre os conceitos de Direito e Engenharia, numa disciplina que tem se tornado tradicional internacionalmente denominada "Construction Law" ou Direito da Construção, que exige um diálogo constante, numa relação saudável, entre essas duas grandes áreas de conhecimento. 


\section{BIBLIOGRAFIA}

BNDES. O BANCO NACIONAL DO DESENVOLVIMENTO. BNDES Project

Finance. Disponível em: < http://www.bndes.gov.br/SiteBNDES/bndes/bndespt/Institucional/Apoio_Finance iro/Produtos/Project_Finance> Acesso em: 28 mai. 2011

BONOMI, Cláudio A.; MALVESSI, Oscar. Project Finance no Brasil. São Paulo: Atlas, 2004.

BRASIL. PRESIDÊNCIA DA REPÚBLICA. Código Civil. Lei no 10.406, de 10 de janeiro de 2002. Disponível em: $<$ http://www.planalto.gov.br/ccivil_03/LEIS/2002/L10406.htm>. Acesso em: 10 mar. 2011.

BRASIL. PRESIDÊNCIA DA REPÚBLICA. Código Civil. Lei no 3071 de $1^{\circ}$ de janeiro de 1916. Disponível em: $<$ http://www.planalto.gov.br/ccivil/leis/L3071.htm >. Acesso em: 10 mar. 2011.

BRASIL. PRESIDÊNCIA DA REPÚBLICA. Lei da Arbitragem. Lei n. ${ }^{\circ}$ 9.307, de 23 de setembro de 1996. Disponível em: <http://www.planalto.gov.br/ccivil/leis/L9307.htm> Acesso em: 20 mai. 2011.

BRASIL. PRESIDÊNCIA DA REPÚBLICA. Lei de Licitações. Lei no 8.666, de 21 de junho de 1993. Disponível em: <http://www.planalto.gov.br/ccivil_03/Leis/L8666cons.htm> Acesso em: 10 mai. 2011.

BRASIL. PRESIDÊNCIA DA REPÚBLICA. Regime de Concessão de Serviços. Lei $\mathrm{n}^{\circ}$ 8.987, de 13 de fevereiro de 1995. Disponível em: <http://www.planalto.gov.br/ccivil_03/Leis/L8987cons.htm> Acesso em: 25 abr. 2011.

CAVALCANTI, Flávio de Queiroz Bezerra. Caso fortuito e força maior frente a técnica securitária. Jus Navigandi, Teresina, ano 7, n. 56, 1 abr. 2002. Disponível em: <http://jus.uol.com.br/revista/texto/2829>. Acesso em: 25 mai. 2011. 
CINTRA, Antonio Felix de Araujo; BERGER, Renato. Lei aplicável: uma questão de escolha. Jus Navigandi, Teresina, ano 9, n. 250, 14 mar. 2004. Disponível em: <http://jus.uol.com.br/revista/texto/4942/lei-aplicavel-umaquestao-de-escolha>. Acesso em: 26 mai. 2011.

DINIZ, Maria Helena. Teoria das obrigações contratuais e extracontratuais. 18ª ed., V. 3, Ex. 6, São Paulo: Saraiva, 2003.

ENEI, José Virgílio Lopes. Project Finance. São Paulo: SARAIVA, 2007.

GOMES, Orlando. Contratos. 18ª ed. Rio de Janeiro: Forense, 1999.

GÓMEZ, Luis Alberto. Contratos Epc Turn Key. São Paulo: Visual Books, 2006.

HUSE, Joseph A. Understanding and negotiating turnkey and EPC contracts. Thomsom Sweet and Maxwel, 2002.

KPMG, Cutting Through Complexity. KPMG International and Infrastructure Journal Announce the Top 100 Infrastructure Projects. Disponível em: <http://www.kpmg.com/Ca/en/IssuesAndInsights/Articles Publications/Press-Releases/Pages/KPMGInternationalandInfrastructureJou rnalAnnouncetheTop100InfrastructureProjects.aspx $>$ Acesso em: 24 jun. 2010 .

NALIM, Paulo. Do contrato - conceito pós moderno. $1^{\mathrm{a}}$ ed. $5^{\mathrm{a}}$ tir. Curitiba: Juruá, 2005.

PEREIRA, Caio Mário da Silva. Instituições de Direito Civil, vol. III. 11 a ed. Rio de Janeiro: Forense, 2004.

PINTO, José Emílio Nunes. O Contrato de EPC para construção de grandes obras de engenharia e o novo Código Civil. Revista da AARJ, Volume III, em Janeiro de 2003.

ROCHA, João Luiz C. da. O moderno contrato de empreitada global. Valor Econômico. Disponível em: <http://www.lexlegis.com.br/leitor_oficial/n 1700/o-moderno-contrato.htm> Acesso em: 14 dez. 2010.

TARTUCE, Flávio. Direito civil - teoria geral dos contratos e contratos em espécie. $3^{\mathrm{a}}$ ed. São Paulo: Método, 2008. 
VENOSA, Silvio de Salvo. Direito Civil - teoria geral das obrigações e teoria geral dos contratos. $3^{\text {a }}$ ed. V. 2, EX. 5, São Paulo: Atlas, 2003.

TURNKEY CONTRACT - Conditions of Contract for EPC/Turnkey Projects

em: $<$ http://www1.fidic.org/resources/contracts/describe/FC-QB-A-AA-10.asp> 